$\mid \begin{array}{cc}\mathbf{C}|\mathbf{O}| \mathbf{P}|\mathbf{E}| & \text { Turyzm/Tourism } \\ \substack{\text { Member since } \\ \text { JM14487 }} & 2021,31 / 2\end{array}$

\title{
REGIONAL TOURISM DURING THE COVID-19 PANDEMIC: LOSSES, MISSED OPPORTUNITIES AND NEW DEVELOPMENTS FOR THE TOURISM INDUSTRY
}

\author{
Beata Gierczak-Korzeniowska ${ }^{a}$ (D), Krzysztof Szpara ${ }^{b}$ (iD, Mateusz Stopac
}

\footnotetext{
${ }^{a}$ University of Rzeszów, Institute of Economics and Finance, Department of Economics and Management; http://orcid.org/0000-0003-2460-2543; e-mail: bgierczak@ur.edu.pl

${ }^{b}$ Polish Geographical Society, Rzeszów Branch; https://orcid.org/0000-0001-8384-9867; e-mail: kszpara@o2.pl

c University of Stavanger, Department of Media and Social Sciences; https://orcid.org/0000-0002-9286-5073;

e-mail: mateusz.b.stopa@uis.no
}

How to cite (APA style): Gierczak-Korzeniowska, B., Szpara, K., Stopa, M. (2021). Regional tourism during the COVID-19 pandemic: Losses, missed opportunities and new developments for the tourism industry. Turyzm/Tourism, 31 (2), 65-86. https://doi.org/10.18778/0867-5856.31.2.04

\begin{abstract}
As a result of the spread of the COVID-19 pandemic, tourism, as one of the branches of many national economies, has suffered heavy losses both nationally and regionally. The pandemic as a global phenomenon is bound to change tourism, at least for some time to come. Therefore, questions arise about the nature of these changes and how deep they will be. The aim of the article is to show that for Podkarpackie Province in Poland, the COVID-19 pandemic, apart from the obvious negative consequences for the tourism industry, has also brought new development opportunities. The analyses presented here are based on a survey conducted among 948 adult respondents in 10 different locations within three districts between 15 and 30 August 2020. The analysis showed that during the pandemic, nature-related travel and active tourism, as well as trips aimed at health recovery were in high demand. Ensuring health and safety on holidays became a priority. Therefore, a concentration of tourism was observed in selected domestic destinations, usually in areas not associated with tourism (e.g. rural areas). In the future, this may create opportunities for a revival of local tourism. In contrast, the tourism industry suffered its greatest losses in cities; business and event tourism lost out, and there was a significant drop in revenue from both domestic and foreign tourists. These results indicate the negative effects of the pandemic, but also show new development opportunities. No one knows how long COVID-19 will continue, so the conclusions may be useful both for entrepreneurs preparing their tourist offers in the coming years, and institutions responsible for regional tourism policy.
\end{abstract}

\section{KEYWORDS}

regional tourism, tourism industry, Podkarpackie Province, COVID-19, analysis of tourism

\section{ARTICLE INFORMATION DETAILS}

Received:

30 August 2021

Accepted:

26 October 2021

Published:

3 December 2021

\section{INTRODUCTION}

Tourism is one of the most important economic sectors providing income for hundreds of millions of people, while enabling countries and regions to develop. However, it is very sensitive to certain situations, especially those affecting tourist safety levels. The COVID-19 pandemic is such a factor.

The article analyses the consequences of the COVID-19 pandemic for the tourism industry using a case study of Podkarpackie province. In August 2020, the Podkarpackie Regional Tourist Organization conducted 
its first research into levels of tourism according to a new cyclical research methodology. The districts of Podkarpackie Province with the highest tourist volume were chosen as a result of the restrictions introduced and the difficulties in otherwise accessing an appropriate number of respondents. The results obtained from more than 900 respondents from the three districts allow for the presentation of a more accurate picture of tourism at this particular time. Moreover, the guarantee of continuation of the research according to an unchanged methodology means that it will soon be possible to answer the question whether and to what extent the pandemic has caused permanent changes in the consumption of tourism.

The aim is to show that, for Podkarpackie Province in Poland, the COVID-19 pandemic, apart from its obvious negative consequences for the tourism industry, has also brought new development opportunities. Hence the title which emphasizes, on the one hand, concrete and calculable losses, but also sometimes completely surprising opportunities for the development of this industry in the new conditions. Importantly, these opportunities were mentioned by the tourists themselves. Therefore, the results can be viewed as consumer opinions formulated under exceptional conditions.

There are many indications that the state of the pandemic will persist not only in 2021, but probably also in 2022, and maybe even longer. Certainly, the industry will take many years to recover from the losses incurred by two or even three years of tourist restrictions and other limitations (Jędrzejowska, Wróbel, 2020; Mirchandani, 2020). Therefore, it can be assumed that the 'exceptional' situation for 2020 will become 'normal' for tourists and many businesses for at least 3-5 years. COVID-19 has also shown that the risk of a global pandemic directly affecting the economy in almost all its dimensions is not abstract at all (Jędrzejowska, Wróbel, 2020).

The article touches on disciplines such as economics and finance, socio-economic geography and spatial management, and sociological sciences because it shows the problems faced by the tourism industry in one of the most important branches of the global economy. The conclusions from the research can be used both by entrepreneurs preparing their tourist offers in the coming years, and by institutions responsible for regional tourism policy.

\section{LITERATURE REVIEW}

\subsection{REgIONAL TOURISM AND THE COVID-19 PANDEMIC}

Both travel and tourism consumption occur at three geographic levels: international, national and regional. Regional tourism is concentrated in an area that can be distinguished from others on the basis of its own culture and structure (Romão, Guerreiro, Rodrigues, 2012). Regional tourism is not only a sense of travelling; it is also the imagination and the expectation of what will be seen, what the challenges will be like, what can be done or who met. Hence, regional tourism and its role are often considered through socio-cultural, economic and environmental dimensions (Sjafii, Pratiwi, 2018).

In the tourism literature, other definitions of regional tourism can be found including one focusing on the geographical scale of the products offered, and another on the geographical origin of tourists. Regional tourism is also associated with domestic tourism which generates the highest number of tourists. This high percentage results from the fact that domestic tourists are familiar with the local socio-economic and cultural environment, as well as the relative proximity of destinations and there are lower travel costs (Pierret, 2011). This article assumes that regional tourism is concentrated in a region as a territorial unit (Chojnicki, Czyż, 1992), in this case Podkarpackie Province. Authorities and regional tourist organisations in such regions have competences that allow a certain scope of action in relation to entities located in their area. They are also responsible for marketing, development and management of tourism at the regional level and the preparation of reports on research including into tourism.

Although regional tourism is an important phenomenon in developing countries, it has been largely marginalised in international research. Its promotion however may positively contribute to the development of a region (Rogerson, Kiambo, 2007), hence its study is very important for its impact on the local economy as well as drawbacks in how it is managed. (Milova, Piskovets, Chernyshenko, 2017). Therefore, it is important to develop strategies and promote the value of tourism by managers at local and regional levels (Carson, Richards, Rose, 2004). It is even emphasized in the literature (Rogerson, Kiambo, 2007) that policy interventions in tourism should be undertaken at both national and local levels in order to maximize the developmental impacts of promoting regional tourism, regardless of the changing political environment. This is justified as the strength of the internal market is of great importance in crisis situations, of which the COVID-19 pandemic is undoubtedly one, and has led to many difficulties for tourism businesses as a result of restrictions on movement.

Personal safety usually constitutes one of the main criteria for selecting a tourist destination and is part of the following triad: attractiveness-safety-cost (Bernaś, Pujer, 2014). It is also an external determinant that has a great influence on travel decisions. Among external determinants, Kurek (2007) lists socio-demographic, economic, technological, political and natural con- 
ditions. Gołembski (2005) adds an increase in the amount of free time, an increase in the level of real income, the popularisation of education, along with changes in culture, what tourists value, the development of transport, industrialisation and urbanisation, infrastructure, and tourism policy. However, fear for personal health, well-being and sometimes even life, often leads to paralysis and a standstill in transport, and thus in tourism.

China was the first country affected by the COVID-19 pandemic, and it was regional tourism in China that was the first to suffer the negative consequences of isolation and restrictions (Ayittei, Ayittei, Chiwero, Kamasah, Dzuvor, 2020). A similar situation occurred in many regions in Italy. In March 2020, in Rome, almost $90 \%$ of hotel and travel agency bookings were cancelled, while in Sicily the rate was 80\% (Folinas, Metaxas, 2020). American Southwest Airlines recorded a noticeable drop in bookings to Las Vegas from February 2020 (Ren, 2020) and Virgin Atlantic confirmed a similar situation for Cyprus in March and April (Tornos, 2020).

The tourism industry, including regional tourism, has lost a lot and will certainly lose a lot more due to the pandemic, but it is also because of domestic tourism one of the few sectors to have gained. Flew and Kirkwood (2021), referring to four regions in Australia, even speak of a possible revival, a renewal of regional tourism, especially in places easily accessible by car and within national boundaries. Indisputably, COVID-19 represents a serious test of the resilience of the tourism sector, and since March 2020 it has prompted many governments to prepare rescue packages. Looking for opportunities to support the local tourism industry, people were encouraged to plan their holidays in their area, emphasising the strengths of the region.

This shows that domestic/regional tourism can be an interesting alternative for residents in times of socioeconomic instability or global threats (Couto et al., 2020). Moreover, it was noted that there is interest in travel offers that aim not only at exploration and leisure, but also recovery, both physical and spiritual. An important motive for this attitude may be a desire to learn about traditional health practices and an interest in complementary medicine to protect 'psycho-spiritual' well-being from further illness. Even if the negative effects of the pandemic crisis are inevitable, at the same time a window is opened to develop new models of regional tourism activities, such as adventure, active and nature tourism, as well as eco- and gastronomic tourism (Castanho, Couto, Pimentel, Carvalho, Sousa, 2020; Ponte, Couto, Pimentel, Oliveira, 2018).

It is also worth mentioning that regional tourism has largely been and continues to be pursued as a necessity, the only option rather than a choice. This was confirmed, for instance, by the study conducted by Couto et al. (2020), in which a significant part of the residents of the
Azores Archipelago (84.2\%) declared that they would take their holidays locally and, therefore, stay in the region. Similar indications can be found in the work of Madani, Boutebal, Benhamid \& Bryant (2020). In this case, Algerian citizens, preferred regional tourism due in part to security issues and the closure of borders. In doing so, they emphasised leisure in nature and forests. Therefore, despite the restrictions imposed by the pandemic, tourists are increasingly discovering their local area and region, as demonstrated by the relaxation of restrictions over the holiday period when regional tourism was the most popular choice.

Concluding, it is worth mentioning that national revenue in Poland does not depend mainly on tourism, but it is crucial for some regions such as the coast, lake districts, or mountain areas like the southern part of Podkarpackie Province.

\subsection{Tourism in the Podkarpackie Region: THE 'PRE-COVID' SITUATION}

Podkarpackie Province is located in the southeastern part of Poland. It covers an area of $17,846 \mathrm{~km}^{2}$ and is inhabited by over 2,127,000 people (Rocznik statystyczny..., 2020). The unique natural environment and cultural heritage of the region, including wooden churches inscribed on the UNESCO World Heritage List, create favourable conditions for the development of tourism. Based on the Local Data Bank (LDB) of the Central Statistical Office of Poland (CSO), it is clearly visible that the number of tourists visiting Podkarpackie Province has been systematically increasing for many years, from around 500,000 in 2004 to almost 1,297,000 in 2019 (Szpara, Gierczak-Korzeniowska, Stopa, 2020b). In 2019, the CSO estimated accommodation capacity in Podkarpackie Province at 652 establishments (including over $75 \%$ open all year round) offering 35,700 beds (including 27,400 all year round). In 2019, 1,297,000 tourists (including 144,100 foreigners) booked 3,602,100 overnight stays (including 279,100 by foreign tourists). Tourism is concentrated in the southern and south-eastern part of the province (especially in the districts of Bieszczady and Lesko) and in Rzeszów (Turystyka..., 2020).

The tourist attractiveness of Podkarpackie Province is connected to its natural diversity which is very important for the multi-directional development of tourism (Szmuc, 2009). One of its assets is its significant forest area (Marszałek, 2020) while the natural heritage of the Carpathians in general is particularly important for the development of tourism (Więckowski, 2020). The most valuable areas of the province are located in its southern, Carpathian, part and Bieszczady and Magura National Parks were established there. The usually underestimated foreland also has significant potential (Szpara, 2020). 
Cultural heritage is an important factor in tourism development (Durydiwka, 2011) and its multicultural heritage is particularly valuable and characteristic of the border region (Skulimowska, 2014). In general, communes located in the southern, Carpathian, part of the province are top-rated tourist attractions, both in the general recreational season and in the winter. Tourism is best developed in the communes of Cisna, Solina and Lutowiska (Pawlusiński, 2009) located in the Bieszczady and the Sanok-Turka Mountains.

Based on this potential, various forms of cognitive tourism, both natural and cultural, are being developed. For example, approximately 571,600 people visited Bieszczady National Park in 2019 (Frekwencja na szlakach w 2019 roku, 2019). In 2018, for selected cultural sites, over 401,000 visited Łańcut Castle Museum, almost 164,000 the Museum of Folk Architecture in Sanok, and over 115,000 went to the castle and park in Krasiczyn (Nycz, 2019). Culinary tourism is particularly valuable and characteristic of the region (Krupa, Mantaj, 2017; Krupa, Zielinski, 2015; Zielinski, 2019) including oenotourism which uses the potential of the vineyards in the province (Reczek, 2019).

Rural tourism, including agrotourism, is developing in Podkarpackie Province, especially in its southern part (Durydiwka, 2012; Szpara, 2011a; Tracz, BajgierKowalska, Uliszak, 2017). There are various forms of active tourism (Rut, 2002; Śmiały, 2007; Widak, 2020a; Widak, 2020b) while spas located in the region also have significant potential (Filozof, 2019). The rich sacred sphere in the cultural landscape (Baran-Zgłobicka, 2013), including numerous sanctuaries and pilgrimage centres (Mróz, Mróz, 2012), influences the development of religious tourism. Urban, business and event travel are gaining in importance as well.

Tourism in Podkarpackie Province has been the subject of numerous studies and analyses. The first comprehensive study of tourism was conducted in 2009 (Szpara, 2011b; Szpara et al., 2009) and repeated in 2011 with a slightly different approach (Badanie ruchu turystycznego..., 2011). After many years, the idea of cyclical research was revived, in 2020 a methodology was developed (Szpara, Gierczak-Korzeniowska, Stopa, 2020a) and pilot studies were conducted (Szpara, Gierczak-Korzeniowska, Stopa, 2020b).

Regardless of regional research on tourism, research into its image (Badanie potencjału turystycznego, 2018) was undertaken, as well as on selected issues in the province including tourism potential (Ślusarz, CierpiałWolan, Gierczak-Korzeniowska, Uchman, Żegleń, 2019), regional tourism brands (Gierczak-Korzeniowska, 2019), local products (Niziol, 2016), the opinions of internet users on Podkarpackie Province as a tourist destination (Stokłosa, Marchiori, Piotrowski, Cantoni, 2013), as well as tourism staff (Szpara, Skała, 2008) or the selected profiles of tourists (Szpara, 2015).

\section{RESEARCH METHOdology}

The analyses presented in the paper are based on a survey conducted by the Podkarpackie Regional Tourist Organisation (PRTO) among 948 adult respondents in ten different locations within three districts between 15 and 30 August 2020. The sample itself was random and representative of the total population of tourists coming to Podkarpackie Province, the measurement error was $\pm 5 \%$ (at confidence level alpha 0.95 and $50 \%$ fraction).

The first step of sample construction was an analysis of public statistics and the selection of the three districts with the greatest tourist volumes in 2019, including Rzeszów powiat and the districts of Lesko and Bieszczady. Then, a committee of independent tourism experts indicated the most important tourist destinations in these districts; ultimately ten locations ${ }^{1}$ were chosen for sampling where mass tourism was most likely to occur.

The interviewers had to conduct the surveys on specific weekdays with breaks of at least four days between each survey. Moreover, two days for the survey were scheduled during weekdays, and two others at weekends. Each interviewer in every location was instructed to interview every $15^{\text {th }}$ adult passer-by.

The survey was conducted on August $15^{\text {th }}$ (Saturday), $20^{\text {th }}$ (Thursday), 25 $5^{\text {th }}$ (Tuesday) and $30^{\text {th }}$ (Sunday). Both in the districts of Bieszczady and Lesko, all questionnaires were administered in a traditional pen and ink version (67\% of all surveys) due to internet connection issues, while in Rzeszów, Computer-Assisted Personal Interviewing was used (33\% of all surveys). The tool consisted of two main parts including questions about facts (socio-demographic features, travel arrangements to the destination (transport, accommodation), funds allocated for the trip, travel and how time was spent), and questions about opinions (tourism assets of Podkarpackie Province, assessments of tourism and accompanying services and infrastructure, the general image of the province, and consumer loyalty). The questionnaire was characterised by a high degree of standardisation, containing only a few open questions, while the vast majority were closed or semi-open (with the question 'other: what kind?' at the end), at nominal and ordinal measurement levels. The average time for the survey did not exceed 15 minutes while information on an average of 290 variables was aggregated from them.

In terms of statistical analysis, the main test for relationships and dependencies was the chi-square independence test. To judge whether there were statistically significant differences between averages, an analysis for variance (ANOVA) procedure was implemented. 


\section{THE COVID-19 PANDEMIC AND IMPLICATIONS FOR THE TOURISM INDUSTRY in PodkARPACKIE PROVINCE}

The tourism industry is and certainly will be affected by the far-reaching effects of the COVID-19 pandemic outbreak (Chang, McAleer, Ramos, 2020). Throughout human history, times of crisis have always preceded periods of change and the current health, economic and social crises will be no exception (Cauto et al., 2020). In the tourism industry, this will translate into changes in both demand (e.g. changes in travel patterns, travel behaviour and destination choice) and supply (e.g. the modification and change of offers taking health and safety into account). But will the pandemic only result in losses and the collapse of the tourism industry? Or maybe this unprecedented situation will create new opportunities and behaviours which are a manifestation of adaptation to the difficult conditions created by COVID-19.

When at the end of May and the beginning of June the number significantly of cases started to decrease in Poland, people were granted freedom of movement and could plan their holidays. What turned out to be significant was that holiday plans were mainly focused on domestic destinations and many interesting changes in tourist choices and practices were identified. In August 2020, research on tourism in Podkarpackie Province showed that tourists' length of stay had changed significantly. The way in which arrivals and stays were organised was also of importance to the tourism industry, and trips in smaller groups were more often preferred, while safety and numerous restrictions determined the choice of travel model and means of transport. ${ }^{2}$

Therefore, with these changes in mind, the author decided to look at the problem in two ways, not only through the threats and negative effects that are the obvious result of the pandemic, but also the opportunities and new possibilities that this new situation had brought with it.

\subsection{NEGATIVE IMPACTS AND MISSED OPPORTUNITIES IN THE TOURIST INDUSTRY}

Pandemics of all kinds, including the current COVID-19, directly affect the tourism industry (Lee, McKibbin, 2004) and the wider tourism economy. The tourism economy includes not only goods and services that directly serve tourism consumption, but also such economic activities that are strictly or partially dependent on tourism and whose development would not be possible (or would be significantly limited) if it were not for tourism (Gołembski, 2020). Tourist research in Podkarpackie Province in August 2020 showed that the tourism industry had lost a lot and the effects of the lockdown and restrictions had a negative impact on the functioning of tourism enterprises and the socioeconomic development in the region.

The first unquestionable consequence of isolation and concerns about the safety of travellers in a wider sense was the lower number of domestic and foreign tourists. The estimate of the number of tourists coming to Podkarpackie Province in 2020 is based on the data of the LDB of the CSO, taking into account the results of a tourist survey conducted in the three districts of Bieszczady, Lesko and Rzeszów in August 2020 at the request of the Podkarpackie Regional Tourist Organisation. In 2019 , the number of tourists was 1,296,747; data on oneday visitors are not published in the LDB. Based on the data on the number of tourists coming to Podkarpackie Province in the period 2002-2019, an attempt was made to estimate the number of tourists in 2020 . The time series model developed with free GRETL software package enabled a forecast for 2020 to be calculated (with an error of $5 \%$ ) of between 1,027,341 and 1,459,122 visitors (not taking the pandemic into account), including foreign tourists ranging from 191,430 to 352,018. The means for the adopted ranges were defined as 1,243,231 for tourists in total, and 271,724 for foreigners.

This is the number of tourists (including foreigners) that - according to the trend based on the time series - could have arrived in Podkarpackie Province in 2020, had it not been for such a significant disturbance as the pandemic-related restrictions. Bearing in mind that, on average, foreign tourists accounted for $10 \%$ of those in the province, and also knowing the relation of non-resident tourists to the total number surveyed, it was assumed that tourism would decrease by at least $26 \%$, which in absolute numbers meant no more than 919,991, including four times fewer non-resident tourists (foreigners) i.e. a maximum of 67,931 who permanently live outside Poland. In March 2021, the CSO provided information (Turystyka na Podkarpaciu w 2020 roku, GUS, 03.2021) which indicated that according to official data, 710,300 tourists, including 44,800 foreign, used accommodation facilities in Podkarpackie Province. It should be added here that the CSO data are aggregated from accom modation facilities with more than ten beds and do not include agrotourism. On the other hand, the research showed that tourists looked for such accommodation. It can, therefore, be assumed that the official data underestimated the reality, and actual tourism decreased by $30 \%$ rather than $45.2 \%$, as reported by the CSO.

What is important for the interpretation of the above data is that the research was conducted in August 2020, and the summer months were a period when restrictions had been temporarily lifted for the tourism industry. The autumn period brought another wave of the pandemic and an even deeper stagnation. It is, 
therefore, difficult to accurately estimate the number of tourists travelling under the restrictions on tourism in 2020. It should be remembered that most analyses and information are based on forecasts and calculations that refer to a constantly changing pandemic situation, a process which continues and is characterised by varying degrees of intensity in individual regions. However, the data on an almost $75 \%$ decrease in the number of foreign tourists coming to Podkarpackie Province coincide, among others, with data in the work of Sigala (2020) who stated that already in May 2020, due to the outbreak of the pandemic, it was expected that international tourism would decrease by $78 \%$, and with OECD estimates which assumed a $60 \%$ decrease in international tourism in 2020 (Madani, Boutebal, Benhamida, Bryant, 2020).

Significantly lower tourist levels in Podkarpackie Province and the resulting collapse in demand for tourist goods and services caused financial losses. Assuming that in 2020 Podkarpackie Province was visited by at most 919,991 tourists (i.e. 323,240 fewer) with the revenue from one tourist being in the range of PLN $850-1,000$ as estimated by the research, in practice this means a loss from PLN 274,754,000 to PLN 323,240,000. On the other hand, it is extremely difficult to estimate the impact generated by one-day visitors. Most of them come from Podkarpackie Province, so it is difficult to speak of external influence (this is money flowing between sectors within the province). For visitors, the largest group (73\%) were those whose expenditure during their stay was in the lowest range and did not exceed PLN 500. Additionally, due to the socio-demographic characteristics (profile) of one-day visitors presented in the research, the range for declared expenditure of PLN 0-500 might have overestimated the average revenue from this type of tourism. The middle of the range indicates that young people from nearby towns spend PLN 250 on a one-day stay, for example, in Rzeszów. The figure of around PLN 100 is much closer to the truth. Taking these assumptions into account, it can be finally assumed that each one-day visitor generates an average revenue of PLN 100. They account for $26.6 \%$ of those surveyed which, in absolute terms, means approximately 244,718 people creating about PLN 24,471,800. This money goes mainly to small catering businesses, shops and shopping centres and selected entertainment.

The negative effects of the pandemic as well as the missed opportunities, especially during the short-term lifting of restrictions, can be discussed with regard to cities (Table 1). Long-term isolation and the need to stay at home influenced the choice of holiday destination for most people. The most popular and safest were natural sites, secluded places outside the city and rich in natural beauty. Thus, urban tourism and cities lost out, and so did all its tourism service providers. This is confirmed by the results of the research in which tourists from outside Podkarpackie Province constituted the vast majority in the districts of Bieszczady (91.4\%) and Lesko $(93.2 \%)$, where the natural environment is the main attraction, while one-day visitors dominated in Rzeszów (66.8\%). These mostly come from Podkarpackie Province $(82.7 \%)$ and are young. The market square $(49.9 \%)$ and shopping centres $(11.7 \%)$ were the dominant attractions and destinations. Therefore, in this case, missed opportunities can be seen in the context of the failure to prepare an offer for such a traveller's profile. There was lack of knowledge and information about recreational, sports or cultural attractions.

The interpretation of the variance test result assumes the adoption of two hypotheses - the null hypothesis, which is an assumption that the variability of the analysed characteristic does not depend on the adopted factor (i.e. on the type of district) and an alternative hypothesis - i.e. an inverse assumption that the variability of the feature is statistically significantly related to the variability of the factor. The level of statistical significance ( $p$ value) means the necessity to reject the null and adopt an alternative hypothesis. For the interpretation of the results, this means that when the value of statistical significance is below the assumed level of 0.05 , an assumption should be made about the significant variation of the analysed feature according to the factor. The article presents only those variables whose variance is statistically significantly different according to the type of district.

Table 1. ANOVA analysis for the main characteristics of visitors with respect to factors influencing the choice of place of stay (Rzeszów / Beszczadzki and Leski districts)

\begin{tabular}{|c|c|c|c|}
\hline Factors & Rzeszów & Beszczadzki and Leski districts & ANOVA ( $p$-value) significance \\
\hline Age of visitors & mostly younger (under 40 ) & mostly older (over 40) & 0.046 \\
\hline $\begin{array}{l}\text { The place of residence } \\
\text { of visitors }\end{array}$ & $\begin{array}{c}\text { mostly within } \\
\text { Podkarpackie Province }\end{array}$ & $\begin{array}{c}\text { mostly outside } \\
\text { Podkarpackie Province }\end{array}$ & 0.000 \\
\hline Form of arrival organisation & \multicolumn{2}{|c|}{ mainly on an individual basis } & 0.669 \\
\hline Length of visitors' stays & mostly one-day visitors & mostly tourists & 0.000 \\
\hline Nature of stay & mainly passive & mainly active & 0.000 \\
\hline
\end{tabular}

Source: authors. 
On the topic of urban tourism, it should be emphasized that hotels operating in cities were in the worst situation. Data from the LDB of the CSO show that the volume of tourism measured in terms of accommodation capacity had been steadily increasing in Podkarpackie Province since 2004. Following the outbreak of the pandemic hotels closed and lost their guests. The analyses published on 22 October 2020 by the Statistical Office in Rzeszów show that in July and August 2020 there was a $25.1 \%$ decrease in the number of tourists in tourist accommodation establishments compared to the same period in 2019 (Mniej turystów w okresie wakacyjnym, 2020). And it should be borne in mind that this was a period when restrictions were loosened and travel was allowed. Hotels with a large number of beds were at a disadvantage as there were health concerns on the part of customers due to overcrowding in such establishments. The situation of hotels located in non-urban areas was slightly better. At the same time, the respondents were more often than usual interested in accommodation in small establishments allowing for social distancing and other safety rules. Thus, guesthouses were the most popular $(18.2 \%)$, followed by holiday cottages $(14.1 \%)$, while hotels and agrotourism accommodation were third $(12.8 \%)$. Private accommodation and guest rooms $(10.5 \%)$ and accommodation with family or friends $(8.2 \%)$ were also very popular.
Another recorded phenomenon of importance to the region's tourism industry was the way in which arrivals and stays were organised. Individual and small family groups prevailed. Over $95 \%$ of one-day visitors and $70.9 \%$ of tourists organised their arrival and stay on their own. As the research showed, small-group travel was also more frequently preferred to ensure health and safety. Therefore, travel agencies lost out. Safety and numerous other restrictions also determined the choice of the means of transport. Private transport dominated, with over $84 \%$ of tourists and $89 \%$ of oneday visitors reaching their holiday destination by car. Planes, trains or coaches were hardly used. Therefore, public passenger transport companies lost out.

The MICE industry, which is dynamically developing around the world, in Poland and also in Podkarpackie Province, felt the effects of the pandemic painfully. It should be emphasised here that for many people the reason for travelling includes doing business, going to conferences, trade fairs, participation in congresses and business meetings. The development of the MICE industry contributes to economic diversification (Rogerson, 2017), stimulates the rational use of cultural and natural-recreational resources, and enables the sustainable development of the entire tourism sector (Astakhova, 2019; Manzoor, Wei, Asif, 2019). It is also the primary source of income for city hotels. Research

Table 2. Negative and positive effects of the COVID-19 pandemic in Podkarpackie Province (Poland)

\begin{tabular}{|c|c|c|c|}
\hline No. & Area of analysis & $\begin{array}{l}\text { Missed opportunities } \\
\text { for the tourism industry }\end{array}$ & $\begin{array}{l}\text { New opportunities and prospects } \\
\text { for the development of the tourism industry }\end{array}$ \\
\hline 1 & Origin of tourists & $\begin{array}{l}\text { Reduction of significance of outbound } \\
\text { and inbound tourism (foreigners) }\end{array}$ & $\begin{array}{l}\text { Increase in significance of domestic and regional } \\
\text { tourism }\end{array}$ \\
\hline 2 & Volume of tourists & $\begin{array}{l}\text { Decrease in the number of domestic and } \\
\text { foreign tourists to the province }\end{array}$ & $\begin{array}{l}\text { Increase in the number of tourists in selected } \\
\text { sub-regions (e.g. Bieszczady) }\end{array}$ \\
\hline 3 & Length of stay & Decrease in importance of transit tourists & Increase in importance of long stays \\
\hline 4 & Purpose of stay/demand & $\begin{array}{l}\text { Lower demand for urban tourism - lack } \\
\text { of interest in urbanized and densely } \\
\text { populated places. Stagnation in business, } \\
\text { congress, event and meeting travel }\end{array}$ & $\begin{array}{l}\text { Increased demand for rural, nature and active } \\
\text { tourism }\end{array}$ \\
\hline 5 & $\begin{array}{l}\text { Consequences } \\
\text { for the tourism } \\
\text { industry }\end{array}$ & $\begin{array}{l}\text { Collapse or struggle of many tourism } \\
\text { businesses (e.g. in large cities). } \\
\text { Discontinuation or reduction of the use } \\
\text { of the services of travel agencies, } \\
\text { accommodation and catering } \\
\text { establishments and public passenger } \\
\text { transport operators }\end{array}$ & $\begin{array}{l}\text { Testing of various solutions enabling online } \\
\text { cooperation, which in the future may enrich the } \\
\text { offer of business, event and meeting travel. } \\
\text { Activating areas so far overlooked or } \\
\text { underestimated (e.g. enriching the offer for sports } \\
\text { groups and individual tourists). } \\
\text { Increase in hygiene and sanitary standards in } \\
\text { accommodation, transport and catering facilities, } \\
\text { as well as in tourist attractions, which in the future } \\
\text { may result in a higher level of service quality }\end{array}$ \\
\hline 6 & $\begin{array}{l}\text { Revenues from tourism } \\
\text { in the region }\end{array}$ & $\begin{array}{l}\text { Significant decrease in revenues from } \\
\text { tourism in the province }\end{array}$ & $\begin{array}{l}\text { Increase in revenues from tourism in some } \\
\text { sub-regions (e.g. in Bieszczady), in certain seasons } \\
\text { (in summer) and for offers targeted towards } \\
\text { an individual tourist }\end{array}$ \\
\hline
\end{tabular}

Source: authors based on research conducted by Podkarpackie Regional Tourism Organisation (PRTO) in Podkarpackie Province in 2020 . 
has shown that the outbreak of the COVID-19 pandemic, with consequent hotel closures, cancellation of both domestic and international flights and numerous restrictions, hit the MICE industry hard. The research conducted in August 2020 showed that only 6.5\% of tourists came to Podkarpackie Province on business. For one-day visitors, the figure was $21 \%$.

And finally, transit tourism, which is important because of the border location of Podkarpackie Province, lost out. It is often associated with shopping trips, but also facilitates the development of other types of tourism. In this case, the research in August captured only four tourists $(0.6 \%)$ and two one-day visitors $(0.8 \%)$ who declared 'transit'. Table 2 (see p. 71 ) shows the negative effects of the pandemic and the opportunities for the tourism industry in Podkarpackie Province.

\subsection{NEW OPPORTUNITIES AND PROSPECTS}

\section{FOR THE DEVELOPMENT OF THE TOURISM INDUSTRY}

Every crisis and the numerous socio-economic challenges associated with them tend to intensify efforts to limit the negative effects while seeking beneficial solutions and new opportunities. This was also the case here, the COVID-19 pandemic showed new opportunities and prospects for the development of the tourism industry. They are worth paying attention to because nobody knows how long the current situation under pandemic restrictions will have to be faced.

The closure of borders, inertia in international tourism and travel safety concerns resulted in increased interest in domestic and regional tourism which should be a significant contribution to building a certain trend for taking domestic holidays. According to the research in the Bieszczady National Park, tourist volumes increased by about 30\% compared to August 2019. This may have been due to the desire to stay in an environment that allows for outdoor recreation and away from larger population centres. Tourists tried to reach a certain compromise. On the one hand, they wanted to enjoy their summer holidays despite the pandemic, and on the other, they tried to reduce the risk of contracting COVID-19 and the possible consequences of quarantine abroad. Hence, it became popular to have a holiday in a region widely recognized as attractive for tourists in view of the natural environment, with the opportunity to stay outdoors and pursue active forms of recreation.

Active tourism was the main purpose for visiting Podkarpackie Province for tourists $(87.9 \%)$ and oneday visitors $(62.3 \%)$ in 2020 (Table 3). Within this category, tourists most frequently indicated hiking $(67.3 \%)$, cycling $(5.3 \%)$ and sailing $(4.2 \%)$, and one-day visitors - hiking (24.6\%), cycling (3.2\%), fishing (2.0\%), canoeing and horse riding (1.6\%). Thus, the motivations and preferences of travellers changed significantly. Long-term isolation and numerous restrictions on physical activity and movement resulted in an increase in interest in active tourism. There was great interest in offers that, in addition to leisure and exploration, enabled health recovery (both physical and mental).

Therefore, when undertaking promotional activity, especially in the event of a prolonged pandemic, it is necessary to emphasize the advantages of the region which enable attractive and safe leisure (e.g. natural and cultural attractiveness as well as the diversity and potential of agrotourism, aimed at families with children, opportunities for active individual tourism, e.g. mountain hiking or canoeing). Wherever it is justified, measures should be taken to improve facilities for active tourism, e.g. by building cycle paths.

Among one-day visitors, the model of one specific destination was dominant (mainly a specific centre and walking between individual attractions), while among tourists it was a single unit of accommodation which acted as the starting point for both active and passive recreation (which is particularly important in the context of a longer period of stay). Information on the dominant models together with the profile of tourists and their declarations of expenditure provide the basis for the preparation of an appropriate tourist offer and enable the identification of travel segments.

Table 3. ANOVA analysis for the main characteristics of visitors with respect to factors influencing the nature of the stay (active/passive)

\begin{tabular}{|l|c|c|c|}
\hline \multicolumn{1}{|c|}{ Factors } & Mainly passive & Mainly active & $\begin{array}{c}\text { ANOVA } \\
\text { (p-value) significance }\end{array}$ \\
\hline Age of visitors & \multicolumn{2}{|c|}{ for all age categories - mainly active } & 0.157 \\
\hline $\begin{array}{l}\text { The place of residence } \\
\text { of visitors }\end{array}$ & $\begin{array}{c}\text { mostly within } \\
\text { Podkarpackie Province }\end{array}$ & $\begin{array}{c}\text { mostly outside } \\
\text { Podkarpackie Province }\end{array}$ & 0.000 \\
\hline Form of arrival organisation & mostly organised by a travel agent & mostly orgnised individually & 0.002 \\
\hline Length of visitors' stays & mostly one-day visitors & mostly tourists & 0.000 \\
\hline Place of stay & Rzeszów & Beszczadzki and Leski districts & 0.000 \\
\hline
\end{tabular}


In Podkarpackie Province, a significant increase in long stays was recorded. Tourists most often decided to stay 14 or more nights $(30.7 \%)$ or between 7 and 13 nights (30\%). This choice was largely dictated by the necessity and willingness to take a holiday for fear of not having this opportunity in the near future due to the uncertain pandemic situation. The data should provide an opportunity for tourism operators to develop an interesting and innovative (network) tourism product based on the natural assets of a region, its culture and traditions, and taking into account a financially attractive purchase (combined promotions).

From the perspective of the promotion of the region and how to communicate with potential tourists, information transfer is also important. The results of the research showed that the internet was the key source of knowledge about Podkarpackie Province and its attractions. For one-day visitors, this share was over $30 \%$, and for tourists, almost $70 \%$. In principle, this information is not surprising. For many years a significant part of society has been gaining information about tourist offers online and it applies more often to younger people, but older people have also become more familiar with the virtual world. Due to restrictions on mobility during the pandemic, many people spent much more time at home than before eagerly using the internet which became a kind of window on the world. Therefore, in order to reach potential tourists and oneday visitors, it seems justified to use the internet as a communication tool (including Google as the most frequently used browser and Facebook as the most frequently indicated form of social media). Special attention should be paid to the qualitative presentation and description of the region's attractions, especially on the websites devoted to Podkarpackie Province used by tourists and one-day visitors looking for information before their arrival. The information should be clear, specific, unambiguous, easy to find, accessible to foreigners and, most of all, up-to-date.

Finally, it is worth noting and using the potential of the satisfaction and loyalty of both tourists and one-day visitors, to promote the tourist attractions of Podkarpackie Province. In the research, the consumer loyalty index consisted of tourists' reviews on satisfaction with their current stay, their plans to visit the same and new locations in the province again in the coming year, and recommending a stay in the region to friends and family. Holidays in Podkarpackie Province definitely $(65.3 \%)$ met tourists' expectations. They declared that within the next 12-18 months they would definitely $(52.6 \%)$ or rather $(30.7 \%)$ like to return to the same places they visited during their last stay. Most respondents would definitely (74.6\%) or rather (21.9\%) recommend a stay in Podkarpackie Province to their relatives or friends. The stay in the province definitely $(66.3 \%)$ met the expectations of one-day visitors.
They declared that within the next 12-18 months they would definitely (61.9\%) or rather (31.0\%) wish to return to the same places they visited during their last stay. Most respondents would definitely $(68.7 \%)$ or rather $(25.8 \%)$ recommend a stay in the region to their relatives or friends. The analysis shows that respondents show a high level of loyalty: $95 \%$ of tourists and $96 \%$ of oneday visitors can be classified as loyal consumers (the total for 'definitely loyal' and 'rather loyal').

The results of the study clearly show that loyal tourists visit the province (repeatedly returning, recommending) and it is they who can be the real brand ambassadors.

\section{SUMMARY AND CONCLUSIONS}

The analyses presented in the article lead to the conclusion that the consequences of the COVID-19 pandemic for the regional tourism industry are not unambiguously positive or negative. The pandemic had a negative impact on the volume of tourism in Podkarpackie Province; it is estimated that instead of the possible 1,400,000, there were fewer than 920,000 tourists at most. The decrease in the number of tourists translated into financial losses for the tourism industry. When analysing the declarations of respondents as to the scale of expenditure, it can be concluded that in 2020 Podkarpackie Province lost between PLN 275 and 323 million. The tourism of the province's residents was not able to compensate for this loss and, for obvious reasons, it did not affect the inflow of cash from outside (it was turnover of money within the region).

Losses affected urban tourism to the greatest extent. In particular, stagnation was observed in business, congress, event and meeting travel. International and transit tourism were significantly reduced.

For safety reasons, tourists chose to have holidays near their place of residence or in neighbouring regions (provinces). They tried to avoid overcrowded places. They preferred active leisure, which may have resulted from the desire to unwind after quite a long time of isolation and under restrictions. One such region was the southern part of Podkarpackie Province (especially the Bieszczady Mountains), where an increase in the number of tourists was recorded, and tourism representatives generally reported a successful summer season.

Nobody knows how long the current situation under pandemic restrictions will have to be faced. Perhaps COVID-19 will remain, even forever, so it must be learned to live with and tourism looked at in a different way. Being aware of the inevitable changes, many tourism managers and entrepreneurs should already be focusing their activities on making plans that will 
allow them to operate in a different reality. The research results, observations and conclusions presented may be helpful in achieving these plans. At the same time, it is advisable to continue monitoring the situation in order to capture changes and trends in regional tourism.

The analyses and data presented in this article relate to the tourism industry in Podkarpackie Province and, due to its specificity, can only contribute to a limited extent to any generalization of the results.

\section{ENDNOTES}

${ }^{1}$ Indicated locations: the Market Square in Rzeszów, Solina - the Solina Dam, Uherce Mineralne - Bieszczady Bicycle Trolleys, Majdan - Bieszczady Forest Railway, Wetlina - the entrance to the trail towards Orłowicza Pass, Cisna - the centre, Wołosate - a ticket booth at the trail towards Tarnica, Ustrzyki Górne - the centre, Ustrzyki Dolne - the centre, Wyżniańska Pass - the car park at the entrance to Połonina Caryńska and Wielka and Mała Rawka.

${ }^{2}$ All definition discussion related to tourism and types of tourism were based on Gaworecki (2010); Kurek, Mika (2008).

\title{
TURYSTYKA REGIONALNA W DOBIE PANDEMII COVID-19 - STRATY, UTRACONE SZANSE I NOWE MOŻLIWOŚCI ROZWOJU BRANŻY TURYSTYCZNEJ
}

\author{
Beata Gierczak-Korzeniowska ${ }^{a}$ (D), Krzysztof Szparab (iD, Mateusz Stopac
}

\author{
${ }^{a}$ Uniwersytet Rzeszowski, Instytut Ekonomii i Finansów, Katedra Ekonomiki i Zarządzania; http://orcid.org/0000-0003-2460-2543; \\ e-mail: bgierczak@ur.edu.pl \\ ${ }^{b}$ Polskie Towarzystwo Geograficzne, Oddział w Rzeszowie; https://orcid.org/0000-0001-8384-9867; e-mail: kszpara@o2.pl \\ c Uniwersytet w Stavanger, Wydział Mediów i Nauk Społecznych; https://orcid.org/0000-0002-9286-5073; \\ e-mail: mateusz.b.stopa@uis.no
}

Sposób cytowania (styl APA): Gierczak-Korzeniowska, B., Szpara, K., Stopa, M. (2021). Regional tourism during the COVID-19 pandemic: Losses, missed opportunities and new developments for the tourism industry. Turyzm/Tourism, 31 (2), 65-86. https://doi.org/10.18778/0867-5856.31.2.04

\begin{abstract}
ABSTRAKT
W wyniku rozprzestrzeniania się pandemii COVID-19 turystyka jako jedna z gałęzi gospodarki wielu państw odniosła duże straty, zarówno w wymiarze krajowym, jak i regionalnym. Pandemia jako zjawisko ogólnoświatowe na pewno zmieni turystykę, przynajmniej na jakiś czas. Powstaje zatem pytanie, jaki charakter przybiorą te zmiany i jak głębokie będą. Celem artykułu jest pokazanie - na przykładzie województwa podkarpackiego w Polsce - że pandemia COVID-19 oprócz oczywistych negatywnych konsekwencji w branży turystycznej przyniosła także nowe możliwości rozwoju. Prezentowane w tekście wnioski dotyczą wyników badania przeprowadzonego w dniach 15-30 sierpnia $2020 \mathrm{r}$. na próbie 948 respondentów w 10 różnych miejscach pomiarowych zlokalizowanych $\mathrm{w}$ trzech powiatach. Przeprowadzone przez autorów studia pokazały, że w czasie pandemii dużym zainteresowaniem cieszyły się podróże związane z naturą, turystyka aktywna, a także wyjazdy ukierunkowane na poprawę nadszarpniętego zdrowia. Priorytetem stało się zapewnienie bezpieczeństwa zdrowotnego podczas realizacji planów urlopowych. W związku z tym zaobserwowano koncentrację ruchu turystycznego w wybranych destynacjach krajowych - zwykle na obszarach niekojarzonych z dużym zagęszczeniem turystów (np. tereny wiejskie). Otwiera to szansę na odrodzenie turystyki lokalnej w przyszłości. Branża turystyczna najbardziej ucierpiała w miastach; straty odnotowano w odniesieniu do turystyki biznesowej i wydarzeń, zaobserwowano znaczący spadek przychodów zarówno z krajowego, jak i zagranicznego ruchu turystycznego. Wyniki te wskazują na negatywne efekty pandemii, ale pokazują również nowe możliwości rozwoju. Nie wiadomo, jak długo jeszcze potrwa pandemia COVID-19, dlatego też wnioski mogą być przydatne nie tylko dla przedsiębiorców przygotowujących w kolejnych latach ofertę turystyczna, ale także dla instytucji kreujących politykę turystyczną regionu.
\end{abstract}

\section{SŁOWA KLUCZOWE}

turystyka regionalna, branża turystyczna, województwo podkarpackie, COVID-19, badanie ruchu turystycznego

\section{INFORMACJE O ARTYKULE}

Przyjęto:

30 sierpnia $2021 \mathrm{r}$.

Zaakceptowano:

26 października $2021 \mathrm{r}$.

Opublikowano:

3 grudnia $2021 \mathrm{r}$. 


\section{WSTĘP}

Turystyka jest jednym z najważniejszych sektorów gospodarki. Zapewnia środki do życia setkom milionów ludzi, a jednocześnie umożliwia krajom oraz regionom rozwój. Bardzo duży wpływ mają na nią jednak różne sytuacje, szczególnie te, które przekładają się na poziom bezpieczeństwa turystów. Do takich czynników zalicza się pandemia COVID-19.

Artykuł poświęcony jest analizie skutków pandemii COVID-19 na przykładzie podkarpackiej branży turystycznej. W sierpniu 2020 r. Podkarpacka Regionalna Organizacja Turystyczna przeprowadziła pierwsze studium ruchu turystycznego według nowej metodologii badań cyklicznych. Ze względu na wprowadzone obostrzenia i przewidywane problemy z dotarciem do odpowiedniej liczby respondentów zdecydowano się na pomiar w powiatach województwa podkarpackiego, w których ruch turystyczny był największy. Uzyskane wyniki z ponad 900 pomiarów dla trzech powiatów umożliwiają przedstawienie dość dokładnego obrazu ruchu turystycznego w tym szczególnym kontekście czasowym. Co więcej, gwarancja kontynuacji badań zgodnie z niezmienioną metodologią sprawia, że wkrótce będzie także możliwe udzielenie odpowiedzi na pytanie, czy i w jakim stopniu pandemia wywołała trwałe zmiany $\mathrm{w}$ konsumpcji turystycznej.

Celem artykułu jest pokazanie - na przykładzie województwa podkarpackiego w Polsce - że pandemia COVID-19 oprócz oczywistych negatywnych konsekwencji w branży turystycznej przyniosła także nowe możliwości rozwoju. W tytule z jednej strony podkreślono straty, a z drugiej perspektywy rozwoju tej branży w nowych warunkach. Co ważne, te możliwości zostały uchwycone w deklaracjach turystów. Wyniki można więc potraktować jako opinie konsumentów, sformułowane w wyjątkowych okolicznościach.

Wiele wskazuje na to, że pandemia utrzyma się nie tylko w 2021, ale zapewne także w 2022 r., a może nawet dłużej. Z całą pewnością branża będzie przez wiele lat odbudowywać się po stratach poniesionych w wyniku obowiązujących przez dwa, czy nawet trzy lata ograniczeń w ruchu i innych obostrzeń (Jędrzejowska, Wróbel, 2020; Mirchandani, 2020). Można więc przyjąć, że sytuacja, którą w 2020 r. uznawano za wyjątkowa co najmniej przez najbliższe 3-5 lat będzie czymś oczywistym dla turystów i wielu przedsiębiorców. COVID-19 pokazał także, że ryzyko globalnej pandemii rzutującej bezpośrednio na gospodarkę niemal we wszystkich jej aspektach wcale nie jest czymś abstrakcyjnym (Jędrzejowska, Wróbel, 2020). Wnioski z badań mogą zostać wykorzystane zarówno przez przedsiębiorców przygotowujących ofertę turystyczną w kolejnych latach, jak i przez instytucje kreujące politykę turystyczną regionu.

\section{PRZEgląd Literatury}

\subsection{TURYSTYKA REGIONALNA A PANDEMIA COVID-19}

Zarówno podróże, jak i konsumpcja turystyczna występują na trzech poziomach geograficznych: międzynarodowym, krajowym i regionalnym. Turystyka regionalna koncentruje się w regionie, czyli obszarze, który można odróżnić od innych terytoriów na podstawie odrębnej kultury oraz struktury (Romão, Guerreiro, Rodrigues, 2012). Turystyka regionalna to nie tylko ruch w sensie przemieszczania się, ale także wyobrażenia i oczekiwania odnośnie do tego, co uda się zobaczyć na trasie, jakie wyzwania staną przed podróżnymi, co będzie można zrobić czy kogo się spotka. W związku z tym turystykę regionalną i jej rolę często rozpatruje się w kontekście społeczno-kulturowym, gospodarczym i środowiskowym (Sjafii, Pratiwi, 2018).

W literaturze przedmiotu możemy ponadto natrafić na dwie różne definicje turystyki regionalnej - jedna koncentruje się na skali geograficznej oferowanych produktów, a druga na pochodzeniu geograficznym turystów. Turystyka regionalna jest także kojarzona z turystyką krajowa, uprawianą przez najwięcej osób na świecie. Ten wysoki odsetek wynika ze znajomości lokalnego środowiska społeczno-gospodarczego i kulturowego przez turystów krajowych, a także ze względnej bliskości miejsc docelowych oraz z niskich kosztów dojazdu (Pierret, 2011). W niniejszej publikacji założono, że turystyka regionalna ogniskuje się $\mathrm{w}$ regionie jako jednostce terytorialnej (Chojnicki, Czyż, 1992) - w tym przypadku w województwie podkarpackim. Władze oraz regionalne organizacje turystyczne na takich terytoriach mają kompetencje umożliwiające podejmowanie pewnych działań w stosunku do podmiotów znajdujących się na podlegającym im obszarze. Odpowiadają także za marketing, rozwój i zarządzanie turystyką na poziomie regionalnym oraz przygotowanie raportów m.in. z badania ruchu turystycznego.

Chociaż turystyka regionalna jest ważnym zjawiskiem w krajach rozwijających się, została w dużej mierze zmarginalizowana $w$ międzynarodowych badaniach. Jej promocja może pozytywnie przyczynić się do rozwoju regionu (Rogerson, Kiambo, 2007), dlatego tak istotne jest badanie turystyki regionalnej i jej wpływu na lokalną gospodarkę oraz problemów wynikających z wadliwego systemu zarządzania (Milova, Piskovets, Chernyshenko, 2017). Ważne są w związku z tym opracowywane strategie oraz promocja wartości turystyki przez menedżerów na szczeblu lokalnym i regionalnym (Carson, Richards, Rose, 2004). W literaturze (Rogerson, Kiambo, 2007) podkreśla się wręcz, że interwencja polityczna w kwestii turystyki powinna być podejmowana zarówno na szczeblu krajowym, jak i lokalnym, aby zmaksymalizować jej wpływ na rozwój turystyki regionalnej, bez względu na zmieniające 
się uwarunkowania polityczne. Jest to uzasadnione, gdyż siła wewnętrznego rynku ma ogromne znaczenie w sytuacjach kryzysowych, do których bezsprzecznie można zaliczyć pandemię COVID-19. Związane z nią ograniczenia w przemieszczaniu się spowodowały bowiem wiele trudności w funkcjonowaniu przedsiębiorstw turystycznych.

Bezpieczeństwo indywidualne zazwyczaj stanowi jedno z głównych kryteriów wyboru miejsca docelowego podróży w celach turystyczno-wypoczynkowych i jest elementem triady: atrakcyjność - bezpieczeństwo - koszt (Bernaś, Pujer, 2014). Jest też jedną z determinant zewnętrznych mających ogromny wpływ na decyzje związane z wyjazdem. Wśród czynników o charakterze zewnętrznym Kurek (2007) wymienia uwarunkowania społeczno-demograficzne, gospodarcze, technologiczne, polityczne oraz przyrodnicze. Gołembski (2005) dodaje zwiększenie ilości czasu wolnego, wzrost poziomu dochodów realnych ludności, upowszechnienie się oświaty i zmiany w sferze obyczajów, rozwój środków transportu, procesy industrializacyjno-urbanizacyjne, walory i infrastrukturę turystyczną oraz politykę turystyczną. Niemniej jednak to obawa o własne zdrowie, dobre samopoczucie, a niekiedy również życie doprowadza często do paraliżu i zupełnej inercji komunikacyjnej, a tym samym turystycznej.

Pierwszym krajem dotkniętym pandemią COVID-19 były Chiny, a co za tym idzie - właśnie w przypadku turystyki regionalnej w tym państwie najwcześniej dostrzeżono negatywne konsekwencje izolacji i obostrzeń (Ayittei, Ayittei, Chiwero, Kamasah, Dzuvor, 2020). Podobna sytuacja zaistniała $\mathrm{w}$ wielu regionach Włoch. W marcu 2020 r. w Rzymie anulowano prawie $90 \%$ rezerwacji w hotelach i biurach podróży, na Sycylii natomiast wskaźnik ten wyniósł 80\% (Folinas, Metaxas, 2020). Z kolei linie Southwest Airlines w USA już w lutym 2020 r. odnotowały zauważalny spadek rezerwacji lotów do Las Vegas (Ren, 2020). Podobną sytuację zaobserwowały w marcu i kwietniu linie Virgin Atlantic w odniesieniu do Cypru (Tornos News, 2020).

Branża turystyczna, w tym turystyka regionalna, wiele straciła z powodu pandemii, ale też zyskała przez wewnętrzny ruch krajowy. Flew i Kirkwood (2021), odnosząc się do opisu czterech regionów w Australii, wspominają wręcz o możliwym odrodzeniu turystyki regionalnej, szczególnie w miejscach, do których łatwo dojechać samochodem oraz zlokalizowanych w granicach państwa. Bezdyskusyjnie COVID-19 stanowi poważny test odporności dla sektora turystycznego i od marca 2020 r. skłonił wiele rządów do przygotowania pakietów ratunkowych. Szukając możliwości wsparcia branży turystycznej na poziomie lokalnym, zachęcano obywateli do planowania wypoczynku w kraju, podkreślając atuty danego regionu.
To pokazuje, że turystyka krajowa/regionalna może stanowić interesującą możliwość podróżowania w sytuacjach różnego rodzaju zawirowań o charakterze społeczno-gospodarczym lub zagrożeń globalnych (Couto i in., 2020). Zauważono ponadto, że zainteresowanie wzbudzają nie tylko oferty podróży o charakterze poznawczym i wypoczynkowym, ale także propozycje wyjazdów mających na celu poprawę i wzmocnienie nadszarpniętego zdrowia, zarówno w aspekcie fizycznym, jak i psychicznym. Istotnym motywem przyjmowania takiej postawy może być chęć poznania tradycyjnych praktyk zdrowotnych i zainteresowanie medycyną komplementarną, która korzystnie wpłynie na psychiczny dobrostan i pomoże ochronić się przed kolejnymi chorobami. Nawet jeśli negatywne skutki kryzysu związanego z pandemią są nieuniknione, to jednocześnie sytuacja ta umożliwia zainwestowanie $\mathrm{w}$ nowe modele regionalnej działalności turystycznej, takie jak: turystyka przygodowa, aktywna, przyrodnicza, ekoturystyka czy turystyka gastronomiczna (Castanho, Couto, Pimentel, Carvalho, Sousa, 2020; Ponte, Couto, Pimentel, Oliveira, 2018).

Warto też nadmienić, że turystyka regionalna w dużej mierze była i jest uprawiana jako konieczność, jedyna możliwość, a nie wybór. Potwierdziły to m.in. badania prowadzone przez Couto i in. (2020), w których znaczna część mieszkańców Azorów (84,2\%) zadeklarowała, że wakacje spędzi na miejscu, a zatem zostanie w zamieszkiwanym przez siebie regionie. Podobne wskazania zamieścili w swojej pracy Madani, Boutebal, Benhamida i Bryant (2020). W tym przypadku obywatele Algierii uznali m.in. turystykę regionalną za najbardziej preferowaną ze względu na bezpieczeństwo i zamknięcie granic. Zwracano tu uwagę przede wszystkim na wypoczynek na łonie natury i w lasach. Coraz częściej mamy zatem do czynienia z odkrywaniem przez turystów lokalności i własnego regionu, czego potwierdzeniem jest fakt, że turystyka regionalna była najczęstszym wyborem w okresie wakacyjnym, czyli w czasie gdy poluzowano obostrzenia.

Kończąc niniejsze rozważania warto wspomnieć, że przychody Polski nie są uzależnione głównie od turystyki, ale jest ona kluczowa dla takich regionów, jak: wybrzeże, pojezierza czy obszary górskie, do których należy południowa część województwa podkarpackiego.

\subsection{TURYSTYKA W WOJEWÓDZTWIE PODKARPACKIM - SYTUACJA PRZED PANDEMIĄ}

Województwo podkarpackie znajduje się w południowo-wschodniej części Polski. Zajmuje powierzchnię $17846 \mathrm{~km}^{2}$ i jest zamieszkane przez ponad 2127000 
osób (Rocznik statystyczny..., 2020). Cenne walory środowiska przyrodniczego i dziedzictwa kulturowego regionu, $\mathrm{w}$ tym drewniane świątynie wpisane na listę światowego dziedzictwa UNESCO, stwarzają dogodne warunki do rozwoju funkcji turystycznej. Na podstawie danych z Banku Danych Lokalnych Głównego Urzędu Statystycznego (BDL GUS) można bezsprzecznie stwierdzić, że liczba turystów w województwie podkarpackim od wielu lat systematycznie rośnie - z ok. 500 tys. w 2004 r. do prawie 1297000 w 2019 r. (Szpara, Gierczak-Korzeniowska, Stopa, 2020b).

W 2019 r. GUS szacował wielkość bazy noclegowej w województwie podkarpackim na 652 obiekty (w tym ponad $3 / 4$ całorocznych), w których znajduje się 35700 miejsc noclegowych (w tym 27400 całorocznych). W 2019 r. skorzystało z nich 1297000 osób (w tym 144100 obcokrajowców), którym udzielono 3602100 noclegów (w tym 279100 turystom zagranicznym). Ruch turystyczny koncentruje się w południowej i południowo-wschodniej części województwa (szczególnie w powiatach bieszczadzkim i leskim) oraz w Rzeszowie (Turystyka..., 2020).

Atrakcyjność turystyczna województwa podkarpackiego jest związana z jego różnorodnością przyrodniczą i ma bardzo duże znaczenie dla możliwości wielokierunkowego rozwoju turystyki (Szmuc, 2009). Atutem jest m.in. znaczna lesistość tego regionu (Marszałek, 2020). Szczególnie istotne dla rozwoju turystyki wydaje się dziedzictwo przyrodnicze Karpat (Więckowski, 2020). Najcenniejsze tereny województwa znajdują się w jego południowej, karpackiej części. Utworzono tam Bieszczadzki Park Narodowy i Magurski Park Narodowy. Znaczny potencjał mają też niedoceniane zwykle Pogórza (Szpara, 2020). Ważnym czynnikiem rozwoju funkcji turystycznej tego regionu jest również dziedzictwo kulturowe (Durydiwka, 2011). Szczególnie cenna i charakterystyczna dla obszaru pogranicza jest wielokulturowość (Skulimowska, 2014). Najwyższą klasę atrakcyjności turystycznej, zarówno w sezonie ogólnorekreacyjnym, jak i zimowym, mają gminy znajdujące się w południowej (karpackiej) części województwa. Funkcja turystyczna jest najlepiej rozwinięta w gminach Cisna, Solina i Lutowiska (Pawlusiński, 2009), zlokalizowanych w Bieszczadach i w Górach Sanocko-Turczańskich.

Na bazie tego potencjału rozwijają się różne formy turystyki poznawczej, zarówno przyrodniczej, jak i kulturowej. Przykładowo w Bieszczadzkim Parku Narodowym w 2019 r. odnotowano ok. 571,6 tys. osobowejść (Frekwencja na szlakach w 2019 roku, 2019). Jeżeli chodzi o wybrane obiekty kulturowe, to w 2018 r. Muzeum-Zamek w Łańcucie odwiedziło ponad 401 tys. osób, Muzeum Budownictwa Ludowego w Sanoku - prawie 164 tys. osób, a Zespół Zamkowo-Parkowy w Krasiczynie - ponad 115 tys. osób (Nycz, 2019). Szczególnie cenna i charakterystyczna dla regionu jest turystyka kulinarna (Krupa, Mantaj, 2017; Krupa, Zieliński, 2015; Zieliński, 2019), w tym enoturystyka wykorzystująca potencjał podkarpackich winnic (Reczek, 2019).

Na obszarze województwa podkarpackiego, szczególnie w jego południowej części, rozwija się turystyka wiejska, w tym agroturystyka (Durydiwka, 2012; Szpara, 2011a; Tracz, Bajgier-Kowalska, Uliszak, 2017). $Z$ powodzeniem realizowane są różne formy turystyki aktywnej (Rut, 2002; Śmiały, 2007; Widak, 2020a, 2020b). Duży potencjał tkwi też $\mathrm{w}$ zlokalizowanych $\mathrm{w}$ tym regionie uzdrowiskach (Filozof, 2019). Szeroka sfera sacrum w krajobrazie kulturowym (Baran-Zgłobicka, 2013) - w tym liczne sanktuaria i ośrodki pielgrzymkowe (Mróz, Mróz, 2012) - wpływa na rozwój turystyki religijnej. Na znaczeniu zyskuje turystyka miejska, biznesowa i wydarzeń.

Turystyka w województwie podkarpackim jest przedmiotem licznych badań i analiz. Pierwsze kompleksowe studium ruchu turystycznego przeprowadzono w 2009 r. (Szpara, 2011b; Szpara i in., 2009). W nieco innym ujęciu powtórzono je w $2011 \mathrm{r}$. (Badanie ruchu turystycznego..., 2011). Po wielu latach przerwy powrócono do idei badań, które mają być realizowane cyklicznie. W 2020 r. opracowano metodologię (Szpara, Gierczak-Korzeniowska, Stopa, 2020a) i przeprowadzono badania pilotażowe (Szpara, Gierczak-Korzeniowska, Stopa, 2020b).

Niezależnie od regionalnych studiów nad ruchem turystycznym prowadzono m.in. badania wizerunkowe (Badanie potencjału turystycznego, 2018), a także dotyczące wybranych problemów na terenie województwa, $\mathrm{w}$ tym m.in. wykorzystania potencjału turystycznego (Ślusarz, Cierpiał-Wolan, Gierczak-Korzeniowska, Uchman, Żegleń, 2019), regionalnych marek turystycznych (Gierczak-Korzeniowska, 2019), lokalnych produktów (Nizioł, 2016), opinii internautów na temat województwa podkarpackiego jako obszaru recepcji turystycznej (Stokłosa, Marchiori, Piotrowski, Cantoni, 2013), a także kadr turystycznych (Szpara, Skała, 2008) czy wybranych segmentów turystów (Szpara, 2015).

\section{MetOdy BADAWCZE}

Prezentowane $\mathrm{w}$ tekście analizy dotyczą wyników badania przeprowadzonego przez Podkarpacką Regionalną Organizację Turystyczną (PROT) w dniach 15-30 sierpnia 2020 r. na próbie 948 respondentów w 10 różnych miejscach pomiarowych zlokalizowanych w trzech powiatach. Próba miała charakter losowy i reprezentatywny dla populacji turystów w województwie podkarpackim. Błąd pomiaru wynosił $\pm 5 \%$ (przy założeniu poziomu ufności alfa 0,95 i 50\% frakcji). 
Konstrukcja próby zakładała w pierwszym kroku analizę ogólnodostępnych danych statystycznych na temat wielkości ruchu turystycznego w województwie podkarpackim $\mathrm{w}$ roku poprzedzającym badanie. To umożliwiło wybór trzech powiatów z największym udziałem ruchu turystycznego (powiat grodzki Rzeszów, powiat leski oraz powiat bieszczadzki). W kolejnym kroku komitet niezależnych ekspertów (powołany przez PROT) ustalił kluczowe lokalizacje dla każdego z tych powiatów - ostatecznie wskazano 10 miejsc', w których prawdopodobieństwo wystąpienia masowego ruchu turystycznego było największe.

Ankieterzy byli zobligowani do dokonywania pomiarów w konkretnych dniach tygodnia, z uwzględnieniem co najmniej czterodniowych przerw pomiędzy każdym z dni pomiarowych. Ponadto dwa dni pomiarowe zostały zaplanowane $\mathrm{w}$ tzw. dniach pracujących (poniedziałek-piątek), a dwa pozostałe - $\mathrm{w}$ weekendy (sobota-niedziela). Każdy ankieter miał za zadanie przeprowadzić wywiad kwestionariuszowy we wszystkich wskazanych lokalizacjach z co 15 dorosłą osobą mijająca punkt pomiarowy.

Ostatecznie dniami pomiarowymi były 15 sierpnia (sobota), 20 sierpnia (czwartek), 25 sierpnia (wtorek) oraz 30 sierpnia (niedziela). Zarówno w powiecie leskim, jak i bieszczadzkim ze względu na problemy z zasięgiem łączy internetowych wszystkie kwestionariusze (67\% dokonanych pomiarów) zostały wypełnione z wykorzystaniem tradycyjnej techniki PAPI (ang. Paper and Pencil Interview). W Rzeszowie ankiety zostały przeprowadzone z zastosowaniem metody CAPI (ang. Computer Assisted Personal Interview) - 33\% wszystkich pomiarów uwzględnionych w badaniach. Narzędzie składało się z dwóch głównych bloków, tj. z pytań o fakty (cechy społeczno-demograficzne; schematy organizowania podróży do miejsca pobytu, np. transport, nocleg; środki finansowe przeznaczone na wyjazd; modele podróży i spędzania czasu) oraz pytań o opinie (na temat walorów turystycznych województwa podkarpackiego; oceny usług i infrastruktury turystycznej oraz towarzyszącej; ogólnego wizerunku województwa podkarpackiego; lojalności konsumenckiej). Kwestionariusz charakteryzował się wysokim stopniem standaryzacji - tylko kilka z zawartych w nim pytań było otwartych, podczas gdy zdecydowana większość miała charakter zamknięty lub półotwarty (z kategorią „Inne - jakie?” na końcu) na nominalnym i porządkowym poziomie pomiaru. Średni czas realizacji pomiaru nie przekraczał 15 minut, podczas których przeciętnie gromadzono informacje na temat 290 zmiennych. Pozyskane dane pomiarowe poddane były analizie statystycznej bazującej głównie na teście niezależności chi-kwadrat. W celu rozstrzygnięcia, czy pomiędzy zmiennymi występują istotne statystycznie różnice średnich, przeprowadzono analizę wariancji (ANOVA).

\section{PANDEMIA COVID-19 \\ A KONSEKWENCJE DLA BRANŻY TURYSTYCZNEJ W WOJEWÓDZTWIE PODKARPACKIM}

Branża turystyczna odczuwa i z pewnością będzie odczuwać dalekosiężne skutki wybuchu pandemii COVID-19 (Chang, McAleer, Ramos, 2020). W całej historii ludzkości okresy zmian zawsze były poprzedzone czasami kryzysu. Obecna sytuacja związana z kryzysem zdrowotnym, gospodarczym i społecznym nie będzie wyjątkiem (Couto i in., 2020). W branży turystycznej przełoży się to na zmiany zarówno w popycie (np. w sposobie podróżowania, w zachowaniu podróżujących i wyborze destynacji), jak i podaży (np. modyfikacja ofert, uwzględnianie aspektu zdrowotnego i bezpieczeństwa). Ale czy rezultatem pandemii będą tylko straty i upadek branży turystycznej? A może ta bezprecedensowa sytuacja stworzy nowe możliwości i wpłynie na pojawienie się zachowań, będących przejawem adaptacji do trudnych warunków, stanowiących następstwo rozpowszechnienia się koronawirusa.

Kiedy w Polsce na przełomie maja i czerwca liczba zachorowań zaczęła wyraźnie spadać, ludzie zyskali swobodę przemieszczania się i mogli myśleć o wyjazdach wakacyjnych. Plany urlopowe koncentrowały się głównie na destynacjach krajowych, a w wyborach i praktykach turystycznych dostrzeżono wiele ciekawych zmian. Badania ruchu turystycznego przeprowadzone w sierpniu 2020 r. w województwie podkarpackim pokazały, że istotnej zmianie uległ czas przebywania turystów w miejscach docelowych. Zjawiskiem mającym znaczenie dla branży turystycznej był także sposób organizowania przyjazdu i pobytu. Ponadto zaobserwowano, że najczęściej preferowane były wyjazdy w mniejszych grupach, natomiast bezpieczeństwo i liczne obostrzenia zdeterminowały wybór modelu podróży oraz środka transportu przez przyjeżdżających do danego regionu².

Mając na uwadze wspomniane zmiany, autorzy zdecydowali się rozpatrywać ten problem dwutorowo. Spojrzeli na omawianą kwestię nie tylko przez pryzmat zagrożeń i negatywnych skutków będących oczywistym efektem pandemii, ale również postanowili ją zinterpretować pod kątem szans oraz możliwości, jakie niesie za sobą ta nowa dla wszystkich sytuacja.

\subsection{NEGATYWNE SKUTKI I UTRACONE SZANSE W BRANŻY TURYSTYCZNEJ}

Wszelkiego rodzaju pandemie, w tym obecna-COVID-19, oddziałują bezpośrednio na branżę turystyczną (Lee, McKibbin, 2004) i szeroko rozumianą gospodarkę turystyczną. Do gospodarki turystycznej zaliczamy nie tylko dobra i usługi sprzyjające konsumpcji turystycznej, 
ale także takie rodzaje działalności gospodarczej, które są ściśle bądź częściowo uzależnione od ruchu podróżnych i których rozwój nie byłby możliwy (lub byłby znacznie ograniczony), gdyby nie turystyka (Gołembski, 2020). Badania ruchu turystycznego przeprowadzone w sierpniu 2020 r. na terenie województwa podkarpackiego pokazały, że branża turystyczna wiele straciła, a zamknięcie i restrykcje negatywnie wpłynęły na funkcjonowanie przedsiębiorstw turystycznych i rozwój społeczno-gospodarczy regionu.

Pierwszą niekwestionowaną konsekwencją izolacji i obaw o bezpieczeństwo podróżnych była mała liczba turystów krajowych i zagranicznych. Szacunek dotyczący liczby turystów w województwie podkarpackim w 2020 r. jest oparty na danych Banku Danych Lokalnych Głównego Urzędu Statystycznego, z uwzględnieniem wyników badania ruchu turystycznego przeprowadzonego w sierpniu 2020 r. na zlecenie Podkarpackiej Regionalnej Organizacji Turystycznej w trzech powiatach: bieszczadzkim, leskim oraz w Rzeszowie. Odnotowano, że w 2019 r. uwzględnione w badaniu obszary odwiedziło 1296747 turystów. W BDL nie są publikowane dane dotyczące przyjezdnych jednodniowych. Na podstawie danych BDL GUS dotyczących liczby turystów w województwie podkarpackim w latach 2002-2019 podjęto próbę dokonania szacunku $\mathrm{w}$ odniesieniu do 2020 r. Model szeregu czasowego opracowany w bezpłatnym programie GRETL umożliwił sporządzenie prognozy na 2020 r. (z błędem 5\%), z której wynikało, że liczba turystów będzie się mieścić w przedziale od 1027341 do 1459122 (nie uwzględniano przy tym faktu występowania pandemii), w tym od 191430 do 352018 osób pochodzących z zagranicy. Środki tak przyjętych przedziałów określono jako 1243231 dla turystów ogółem oraz 271724 dla obcokrajowców.

Tylu turystów (w tym również obcokrajowców) - według trendu na podstawie szeregu czasowego - mogłoby przeciętnie dotrzeć do województwa podkarpackiego w 2020 r., gdyby nie pojawiło się tak istotne zaburzenie, jak obostrzenia związane z pandemią. Wiedząc, że przeciętnie turyści z zagranicy stanowili ok. $10 \%$ ruchu turystycznego w województwie, a także znając uchwyconą w badaniu relację turystów nierezydentów wobec ogólnej liczby objętych badaniem turystów, przyjęto ostrożny szacunek, że ruch turystyczny zmaleje co najmniej o $26 \%$, co w liczbach bezwzględnych oznaczało maksimum 919991 turystów, w tym czterokrotnie mniej turystów nierezydentów (obcokrajowców) - czyli maksymalnie 67931 turystów, którzy na stałe mieszkają poza granicami Polski. W marcu 2021 r. ukazała się informacja Głównego Urzędu Statystycznego (Turystyka na Podkarpaciu w 2020 roku, 2021), w której wskazano, że według oficjalnych danych z obiektów noclegowych w województwie podkarpackim skorzystało 710300 turystów, w tym 44800 przyjezdnych z zagranicy. Należy dodać, że dane GUS gromadzone są z obiektów noclegowych, w których znajduje się powyżej 10 łóżek, i nie obejmują informacji z gospodarstw agroturystycznych. Z kolei z przeprowadzonych badań wynika, że turyści właśnie takich noclegów poszukiwali. Można więc przyjąć, że oficjalne dane są zaniżone w stosunku do rzeczywistości i faktyczny ruch turystyczny zmalał raczej o $30 \%$, a nie o $45,2 \%$, jak podaje GUS.

Istotne dla interpretacji przytoczonych danych jest to, że badania ruchu turystycznego przeprowadzono w sierpniu 2020 r., a miesiące letnie były swoistym "okienkiem" w obostrzeniach dla branży turystycznej. W okresie jesiennym rozpoczęła się kolejna fala pandemii, co spowodowało jeszcze większą stagnację w branży. Trudno zatem precyzyjnie szacować liczbę podróżujących w celach turystycznych w warunkach ograniczonego ruchu turystycznego w 2020 r. Należy pamiętać, że większość analiz i informacji bazuje na prognozach oraz obliczeniach, które odnoszą się do stale zmieniającej się sytuacji pandemicznej, czyli procesu, który trwa i charakteryzuje się różną skalą natężenia w poszczególnych regionach. Niemniej jednak dane dotyczące zmniejszenia się liczby turystów zagranicznych w województwie podkarpackim o niemal 75\% pokrywają się m.in. z informacjami zaprezentowanymi w pracy Sigali (2020), która podała, że już w maju 2020 r. w związku z wybuchem pandemii oczekuje się spadku przyjazdów turystów z zagranicy o $78 \%$, oraz z założeniami Organizacji Współpracy Gospodarczej i Rozwoju, przewidującej 60-procentowy spadek w turystyce międzynarodowej w 2020 r. (Madani, Boutebal, Benhamida, Bryant, 2020).

Znacznie mniejszy ruch turystyczny na terenie województwa podkarpackiego, a co za tym idzie - załamanie popytu na dobra i usługi turystyczne stały się przyczyną strat finansowych. Założenia, że w 2020 r. do województwa podkarpackiego dotarło co najwyżej 919991 turystów (czyli mniej o 323240 osób) oraz szacowane na podstawie badania wpływy od jednego turysty mieściły się w przedziale 850-1000 zł, oznaczają w praktyce utratę od 274754000 do 323240000 złotych. Z kolei oszacowanie wpływów z ruchu generowanego przez odwiedzających jednodniowych jest wyjątkowo trudne. W przeważającej części były to osoby z województwa podkarpackiego, zatem trudno tu mówić o wpływach z zewnątrz (były to bowiem pieniądze przepływające pomiędzy branżami wewnątrz województwa). W przypadku odwiedzających największą grupę (73\%) stanowily osoby, których wydatki podczas pobytu mieściły się $\mathrm{w}$ pierwszym przedziale kwotowym i nie przekroczyły 500 zł. Dodatkowo, ze względu na charakterystykę (profil) społeczno-demograficzną odwiedzających jednodniowych, uwzględniony w badaniu przedział deklarowanej kwoty (0-500 zł) prawdopodobnie zawyżał średnie wpływy z tego rodzaju 
ruchu turystycznego. Środek przedziału wskazuje bowiem, że na jednodniowy pobyt np. w Rzeszowie osoby młode, pochodzące z okolicznych miejscowości, przeznaczają 250 zł. Znacznie bliżej stanu faktycznego jest kwota ok. $100 \mathrm{zł}$. Uwzględniając te założenia, można ostatecznie przyjąć, że każdy odwiedzający jednodniowy podczas pobytu wydaje średnio ok. $100 \mathrm{zł}$. Przyjezdni jednodniowi stanowią 26,6\% badanych, co oznacza w liczbach bezwzględnych ruch na poziomie mniej więcej 244718 osób i ok. 24471800 zł przychodu. Pieniądze te są wydawane głównie w dobrych lokalach gastronomicznych, sklepach i centrach handlowych oraz na wybrane usługi rozrywkowe.

O negatywnych skutkach pandemii, ale i o utraconych szansach - zwłaszcza w czasie krótkotrwałego zniesienia obostrzeń - można mówić w odniesieniu do miast (tabela 1). Długotrwała izolacja i konieczność przebywania w domu wpłynęła na wybór miejsca odpoczynku większości osób w okresie wakacyjnym. Najpopularniejsze i najbezpieczniejsze okazały się wyjazdy na łono natury, miejsca odosobnione poza miastem i bogate $\mathrm{w}$ walory przyrodnicze. Straty odnotowano zatem w przypadku turystyki miejskiej i miast oraz wszystkich podmiotów świadczących usługi turystyczne. Potwierdzają to wyniki badań, świadczące o tym, że turyści spoza województwa podkarpackiego stanowili zdecydowaną większość w powiatach bieszczadzkim (91,4\%) i leskim $(93,2 \%)$, w których walory przyrodnicze stanowią główne atrakcje, natomiast w Rzeszowie dominowali odwiedzający jednodniowi $(66,8 \%)$. W większości pochodzili oni z województwa podkarpackiego $(82,7 \%)$ i byli to ludzie młodzi. Dominującymi atrakcjami i celami przyjazdu są rynek $(49,9 \%)$ i galerie handlowe $(11,7 \%)$. O utraconych szansach w tym przypadku może być zatem mowa w kontekście nieprzygotowania oferty dla podróżnych tego typu. Zabrakło wiedzy i informacji o atrakcjach rekreacyjnych, sportowych czy kulturowych.

Interpretacja wyniku testu wariancji pozwala na przyjęcie dwóch hipotez - zerowej, głoszącej, że zmienność analizowanej cechy nie zależy od przyjmowanego czynnika (od typu powiatu), oraz alternatywnej, zakładającej, że zmienność cechy jest w sposób istotny powiązana statystycznie ze zmiennością czynnika. Ze względu na poziom istotności statystycznej ( $p$-value) konieczne jest odrzucenie hipotezy zerowej i przyjęcie hipotezy alternatywnej. W interpretacji wyników oznacza to, że w sytuacji gdy wartość istotności statystycznej plasuje się poniżej zakładanego poziomu 0,05 , należy przyjąć założenie o istotnym zróżnicowaniu analizowanej cechy według czynnika. W tekście zaprezentowano wyłącznie te zmienne, których wariancja jest istotnie statystycznie zróżnicowana pod względem typu powiatów.

Odnosząc się do turystyki miejskiej, należy również podkreślić, że w najgorszej sytuacji znalazły się hotele zlokalizowane w miastach. Według danych pochodzących z Banku Danych Lokalnych Głównego Urzędu Statystycznego wielkość ruchu turystycznego mierzona w bazie noclegowej od 2004 r. w województwie podkarpackim systematycznie rosła. Po wybuchu pandemii hotele zostały zamknięte i straciły swoich gości. Analizy opublikowane 22 października 2020 r. przez Urząd Statystyczny w Rzeszowie pokazuja, że w turystycznych obiektach noclegowych w lipcu i sierpniu 2020 r. zanotowano 25,1\% spadek liczby turystów w stosunku do tego samego okresu w 2019 r. (Mniej turystów w okresie wakacyjnym, 2020). Należy mieć na uwadze fakt, że był to czas poluzowania obostrzeń i przyzwolenia na podróże. W gorszej sytuacji znalazły się hotele z dużą liczbą miejsc noclegowych, ponieważ ze strony klientów pojawiły się obawy o zdrowie w związku z nadmiernym zagęszczeniem $w$ tego typu obiektach. Sytuacja hoteli usytuowanych na obszarach pozamiejskich okazała się nieco lepsza. Przy czym ankietowani byli częściej niż zazwyczaj zainteresowani noclegami w niewielkich obiektach, umożliwiających zachowanie dystansu społecznego i innych zasad bezpieczeństwa. Największą popularnością cieszyły się więc pensjonaty $(18,2 \%)$, na drugim miejscu znalazły się zespoły domków turystycznych $(14,1 \%)$, natomiast na trzecim - ex aequo hotele i kwatery agroturystyczne $(12,8 \%)$. Wielu respondentów było również zainteresowanych kwaterami prywatnymi i pokojami gościnnymi $(10,5 \%)$ oraz noclegami u rodziny lub znajomych $(8,2 \%)$.

Tabela 1. Analiza ANOVA dla głównych cech przyjezdnych w kontekście czynników wpływających na wybór miejsca pobytu (Rzeszów / powiaty bieszczadzki i leski)

\begin{tabular}{|c|c|c|c|}
\hline Czynniki & Rzeszów & Powiaty bieszczadzki i leski & Istotność ANOVA $(p)$ \\
\hline Wiek przyjezdnych & częściej młodsi (do 40 roku życia) & częściej starsi (po 40 roku życia) & 0,046 \\
\hline $\begin{array}{l}\text { Miejsce zamieszkania } \\
\text { przyjezdnych }\end{array}$ & $\begin{array}{c}\text { częściej } \\
\text { z woj. podkarpackiego }\end{array}$ & $\begin{array}{c}\text { częściej spoza } \\
\text { woj. podkarpackiego }\end{array}$ & 0,000 \\
\hline Forma organizacji przyjazdu & \multicolumn{2}{|c|}{ głównie indywidualnie } & 0,669 \\
\hline Długość pobytu & częściej odwiedzający jednodniowi & częściej turyści & 0,000 \\
\hline Charakter pobytu & głównie bierny & głównie aktywny & 0,000 \\
\hline
\end{tabular}

Źródło: opracowanie własne. 
Innym zarejestrowanym zjawiskiem mającym znaczenie dla branży turystycznej $\mathrm{w}$ regionie był także sposób organizowania przyjazdu i pobytu. Dominowały wyjazdy organizowane indywidualnie, w małych rodzinnych grupach. Ponad 95\% odwiedzających jednodniowych i 70,9\% turystów samodzielnie zorganizowało sobie przyjazd i pobyt. Jak pokazały badania, częściej też preferowano wyjazdy $\mathrm{w}$ mniejszych grupach $\mathrm{w}$ trosce o zdrowie i bezpieczeństwo. Spowodowało to odczuwalne straty w przypadku biur podróży. Bezpieczeństwo i liczne obostrzenia determinowały także wybór sposobu lokomocji. Większość respondentów poruszała się własnym środkiem transportu, ponad $84 \%$ turystów i $89 \%$ odwiedzających jednodniowych dotarło do miejsca wypoczynku samochodem osobowym. Badanie wykazało niemal zupełny brak lub niewielki udział takich środków transportu, jak: samolot, pociąg czy autokar. Konsekwencją takiego stanu rzeczy były straty poniesione przez przedsiębiorstwa pasażerskiego transportu zbiorowego.

Równie boleśnie skutki pandemii były odczuwalne w branży MICE, prężnie rozwijającej się na świecie oraz w Polsce (również w województwie podkarpackim).
Należy w tym miejscu podkreślić, że dla wielu osób motywami uprawiania turystyki są: wyjazdy w interesach, konferencje, wyjazdy na targi, uczestnictwo w kongresach i spotkaniach biznesowych. Rozkwit branży MICE przyczynia się do dywersyfikacji gospodarczej (Rogerson, 2017), stymuluje racjonalne wykorzystanie zasobów kulturowych i przyrodniczo-rekreacyjnych oraz umożliwia zrównoważony rozwój całego sektora turystycznego (Astakhova, 2019; Manzoor, Wei, Asif, 2019). Jest też podstawowym źródłem utrzymania hoteli miejskich. Badania dowiodły, że wybuch pandemii COVID-19, a co za tym idzie - zamknięcie hoteli, odwołanie lotów krajowych i międzynarodowych oraz liczne restrykcje, mocno uderzyły w branżę MICE. Badania ruchu turystycznego przeprowadzone w sierpniu $2020 \mathrm{r}$. wykazały, że tylko 6,5\% turystów przyjechało do województwa podkarpackiego w sprawach służbowych. W przypadku odwiedzających jednodniowych odsetek ten wyniósł $21 \%$.

Straty poniosła także turystyka tranzytowa, bardzo istotna ze względu na przygraniczne położenie województwa podkarpackiego, często związana z wyjazdami zakupowymi, ale również ułatwiająca rozwój

Tabela 2. Negatywne i pozytywne skutki pandemii COVID-19 w województwie podkarpackim (Polska)

\begin{tabular}{|c|c|c|c|}
\hline Lp. & Przedmiot analizy & Utracone szanse w branży turystycznej & $\begin{array}{l}\text { Nowe możliwości i perspektywy } \\
\text { rozwoju branży turystycznej }\end{array}$ \\
\hline 1 & $\begin{array}{l}\text { Kierunek } \\
\text { ruchu turystycznego }\end{array}$ & $\begin{array}{l}\text { Ograniczenie znaczenia turystyki } \\
\text { wyjazdowej i przyjazdowej (obcokrajowcy) }\end{array}$ & $\begin{array}{l}\text { Zwiększenie znaczenia turystyki krajowej } \\
\text { i regionalnej }\end{array}$ \\
\hline 2 & $\begin{array}{l}\text { Wielkość } \\
\text { ruchu turystycznego }\end{array}$ & $\begin{array}{l}\text { Spadek liczby turystów krajowych } \\
\text { i zagranicznych w skali województwa }\end{array}$ & $\begin{array}{l}\text { Wzrost liczby turystów w wybranych } \\
\text { subregionach (np. w Bieszczadach) }\end{array}$ \\
\hline 3 & Długość pobytu & Spadek znaczenia turystów tranzytowych & Wzrost znaczenia długich pobytów \\
\hline 4 & Cel pobytu/popyt & $\begin{array}{l}\text { Mniejszy popyt na oferty turystyki miejskiej } \\
\text { - brak zainteresowania miejscami } \\
\text { zurbanizowanymi i gęsto zaludnionymi. } \\
\text { Stagnacja w turystyce biznesowej, } \\
\text { kongresowej, wydarzeń i szkoleniowej }\end{array}$ & $\begin{array}{l}\text { Większy popyt na oferty z zakresu turystyki } \\
\text { wiejskiej, przyrodniczej, aktywnej }\end{array}$ \\
\hline 5 & $\begin{array}{l}\text { Konsekwencje } \\
\text { dla branży } \\
\text { turystycznej }\end{array}$ & $\begin{array}{l}\text { Upadek lub wegetowanie wielu przedsię- } \\
\text { biorstw z branży turystycznej (np. w dużych } \\
\text { miastach). Zaniechanie lub ograniczenie } \\
\text { korzystania z usług biur podróży, obiektów } \\
\text { noclegowych i gastronomicznych oraz } \\
\text { podmiotów zbiorowego transportu } \\
\text { pasażerskiego }\end{array}$ & $\begin{array}{l}\text { Testowanie różnorodnych rozwiązań } \\
\text { umożliwiających współpracę online, } \\
\text { co w przyszłości może wzbogacić oferty z zakresu } \\
\text { turystyki biznesowej, wydarzeń, szkoleniowej. } \\
\text { Aktywizacja niedostrzeganych lub } \\
\text { niedocenianych do tej pory obszarów } \\
\text { (np. wzbogacanie oferty dla grup sportowych } \\
\text { i turystów indywidualnych). } \\
\text { Zwiększenie rygorów higieniczno-sanitarnych } \\
\text { w bazie noclegowej, transportowej } \\
\text { i gastronomicznej oraz w atrakcjach } \\
\text { turystycznych, co w przyszłości może skutkować } \\
\text { wyższym poziomem jakości obsługi }\end{array}$ \\
\hline 6 & $\begin{array}{l}\text { Przychody } \\
\text { z turystyki } \\
\text { w regionie }\end{array}$ & $\begin{array}{l}\text { Znaczny spadek przychodów z turystyki } \\
\text { w skali województwa }\end{array}$ & $\begin{array}{l}\text { Wzrost przychodów z turystyki w niektórych } \\
\text { subregionach (np. w Bieszczadach), w pewnych } \\
\text { porach roku (w lecie) oraz w przypadku oferty } \\
\text { ukierunkowanej na turystę indywidualnego }\end{array}$ \\
\hline
\end{tabular}

Źródło: opracowanie własne na podstawie badań przeprowadzonych przez Podkarpacką Regionalną Organizację Turystyczną (PROT) w 2020 r. w województwie podkarpackim. 
innych rodzajów podróżowania. W trakcie badań przeprowadzonych w sierpniu wśród ankietowanych było zaledwie czterech turystów $(0,6 \%)$ oraz dwóch odwiedzających jednodniowych $(0,8 \%)$, którzy deklarowali przejazd tranzytem. W tabeli 2 (zob. s. 81) przedstawiono negatywne skutki pandemii oraz szanse dla branży turystycznej w województwie podkarpackim.

\subsection{NOWE MOŻLIWOŚCI I PERSPEKTYWY ROZWOJU BRANŻY TURYSTYCZNEJ}

Każdy kryzys i związane z tym liczne trudności o charakterze społeczno-ekonomicznym zazwyczaj niosą ze sobą intensyfikację działań mających na celu ograniczenie skutków negatywnych przy jednoczesnym poszukiwaniu korzystnych rozwiązań oraz nowych możliwości. Tak było również w tym przypadku - za sprawą pandemii pojawiły się nowe szanse i perspektywy rozwoju branży turystycznej. Warto na nie zwrócić uwagę, ponieważ nie wiadomo, jak długo przyjdzie nam mierzyć się z obecną sytuacją i funkcjonować w warunkach ograniczeń spowodowanych pandemią. Być może COVID-19 będzie obecny w świecie przez długi czas, lub nawet już zawsze. Ludzie będą musieli nauczyć się z tym żyć oraz nieco inaczej patrzeć na turystykę.

Zamknięcie granic, inercja w turystyce międzynarodowej i troska o bezpieczeństwo podróżujących spowodowały wzrost zainteresowania turystyką krajową i regionalna, co powinno zapoczątkować swoistą modę na spędzanie urlopu w kraju. Według pomiarów prowadzonych w sezonie letnim 2020 r. w Bieszczadzkim Parku Narodowym ruch turystyczny w stosunku do sierpnia 2019 r. zwiększył się o mniej więcej 30\%. Mogło to wynikać z chęci przebywania w środowisku umożliwiającym wypoczynek na otwartej przestrzeni i z dala od dużych skupisk ludzkich. Turyści starali się wypracować pewien kompromis. $Z$ jednej strony chcieli mimo pandemii udać się na letni wypoczynek, z drugiej zaś - starali się ograniczyć ryzyko zachorowania oraz ewentualnych konsekwencji bycia objętym kwarantanną za granicą. Z tego powodu popularnością zaczął cieszyć się wypoczynek w regionie uznawanym powszechnie za atrakcyjny turystycznie pod względem przyrodniczym, z możliwością przebywania na wolnej przestrzeni i podejmowania różnych form aktywności.

Głównym celem przyjazdu turystów $(87,9 \%)$ i odwiedzających jednodniowych $(62,3 \%)$ do województwa podkarpackiego w 2020 r. była turystyka aktywna (tabela 3). W ramach tej kategorii turyści najliczniej wskazywali wycieczki piesze $(67,3 \%)$ i rowerowe $(5,3 \%)$ oraz żeglarstwo $(4,2 \%)$, a odwiedzający jednodniowi - wycieczki piesze $(24,6 \%)$ i rowerowe $(3,2 \%)$, wędkarstwo (2,0\%), kajakarstwo oraz jazdę konną (1,6\%). Istotnej zmianie uległy zatem motywacje i preferencje podróżnych. Długotrwała izolacja oraz liczne zakazy dotyczące szeroko pojętego wysiłku i przemieszczania się spowodowały naturalny wzrost zainteresowania turystyką aktywną. Dużą popularnością cieszyły się oferty, które poza odpoczynkiem i poznaniem umożliwiały poprawę i wzmocnienie nadszarpniętego zdrowia (zarówno fizycznego, jak i psychicznego).

Podczas przeprowadzania akcji promocyjnej-szczególnie w przypadku przedłużającego się okresu pandemii - należy podkreślać atuty regionu umożliwiające atrakcyjny i bezpieczny wypoczynek (np. walory przyrodnicze i kulturowe oraz różnorodność i potencjał gospodarstw agroturystycznych - dostosowanych do potrzeb rodzin z dziećmi, możliwość uprawiania aktywnej turystyki indywidualnej, np. górskiej turystyki pieszej czy kajakarstwa). Tam, gdzie jest to zasadne, należy podjąć działania związane z poprawą zaplecza dla turystyki aktywnej, np. poprzez budowę ścieżek rowerowych.

Wśród odwiedzających jednodniowych dominował model jednej destynacji (głównie konkretne miasto i piesze przemieszczanie się pomiędzy poszczególnymi atrakcjami). Z kolei turyści najczęściej wybierali model jednego miejsca noclegowego, stanowiącego

Tabela 3. Analiza ANOVA głównych cech osób przyjezdnych w kontekście czynników wpływających na charakter pobytu (aktywny/bierny)

\begin{tabular}{|l|c|c|c|}
\hline \multicolumn{1}{|c|}{ Czynniki } & \multicolumn{1}{|c|}{$\begin{array}{c}\text { Pobyt o charakterze } \\
\text { głównie biernym }\end{array}$} & $\begin{array}{c}\text { Pobyt o charakterze } \\
\text { głównie aktywnym }\end{array}$ & Istotność ANOVA $(p)$ \\
\hline Wiek przyjezdnych & \multicolumn{2}{c|}{$\begin{array}{c}\text { dla wszystkich kategorii wiekowych } \\
\text {-głównie pobyt o charakterze aktywnym }\end{array}$} & 0,157 \\
\hline $\begin{array}{l}\text { Miejsce zamieszkania } \\
\text { przyjezdnych }\end{array}$ & $\begin{array}{c}\text { częściej } \\
\text { z woj. podkarpackiejoj }\end{array}$ & spoza woj. podkarpackiego & 0,000 \\
\hline Forma organizowania przyjazdu & $\begin{array}{c}\text { częściej pobyt organizowany } \\
\text { przez pośrednika }\end{array}$ & $\begin{array}{c}\text { częściej pobyt organizowany } \\
\text { indywidualnie }\end{array}$ & 0,002 \\
\hline Długość pobytu & $\begin{array}{c}\text { częściej } \\
\text { odwiedzający jednodniowi }\end{array}$ & częsiej turyści & 0,000 \\
\hline Miejsce pobytu & Rzeszów & powiaty bieszczadzki i leski & 0,000 \\
\hline
\end{tabular}

Źródło: opracowanie własne. 
bazę wypadową, dzięki czemu mogli sobie pozwolić zarówno na wypoczynek aktywny, jak i bierny (jest to szczególnie ważne w kontekście deklarowanego dłuższego okresu pobytu). Informacje na temat najpopularniejszych modeli, wzbogacone o wiedzę na temat profilu turystów, oraz deklaracje ich wydatków, dają podstawę do przygotowania odpowiedniej oferty turystycznej i umożliwiają identyfikację segmentów podróżnych.

Na terenie województwa podkarpackiego odnotowano istotny wzrost długich pobytów wypoczynkowych. Turyści najczęściej decydowali się spędzić w miejscu docelowym 14 lub więcej nocy $(30,7 \%)$ oraz 7-13 nocy (30\%). Wybór ten w dużej mierze podyktowany był koniecznością i chęcią wykorzystania urlopu w obawie o brak takiej możliwości w najbliższym czasie, ze względu na niepewną sytuację pandemiczną. Dane te powinny stanowić zachętę dla podmiotów w branży turystycznej do opracowania interesującego i innowacyjnego produktu turystycznego (sieciowego), bazującego na walorach przyrodniczych regionu, jego kulturze i tradycji oraz stanowiącego zakup atrakcyjny pod względem finansowym (promocje łączone).

W odniesieniu do promocji regionu i sposobu komunikowania się z potencjalnymi turystami istotny jest również kanał przekazu informacji. Wyniki badań wskazują na to, że Internet był kluczowym źródłem wiedzy o województwie podkarpackim i znajdujących się w nim atrakcjach. Takiej odpowiedzi udzieliło ponad $30 \%$ odwiedzających jednodniowych oraz prawie $70 \%$ turystów. Zasadniczo nie jest to zaskakujące. Od wielu lat znaczna część społeczeństwa pozyskuje informacje na temat oferty turystycznej głównie z zasobów internetowych. Częściej dotyczy to ludzi młodych, jednak coraz sprawniej w wirtualnym świecie radzą sobie również osoby starsze. Ograniczenie możliwości poruszania się podczas pandemii sprawiło, że wiele osób spędza w domu znacznie więcej czasu niż do tej pory. Chętnie korzystają one wówczas z Internetu, który staje się swoistym oknem na świat. Dlatego w celu dotarcia do potencjalnych turystów i odwiedzających jednodniowych zasadne wydaje się wykorzystanie tego narzędzia komunikacji (w tym Google jako najpopularniejsza przeglądarka internetowa oraz Facebook jako najczęściej wskazywane medium społecznościowe). Należy zwrócić szczególną uwagę na jakościową prezentację i opis atrakcji regionu, zwłaszcza na stronach internetowych poświęconych województwu podkarpackiemu, z których korzystali turyści i odwiedzający jednodniowi przed przyjazdem. Zawarte tam informacje powinny być czytelne, konkretne, jednoznaczne, łatwe do znalezienia, dostępne również dla obcokrajowców $\mathrm{i}$ - co bardzo istotne - aktualne.

Warto również zwrócić uwagę na potencjał zadowolenia i lojalności zarówno turystów, jak i odwiedzających jednodniowych w promocji atrakcji turystycznych województwa podkarpackiego i odpowiednio go wykorzystać. W przeprowadzonym badaniu indeks lojalności konsumenckiej składał się z określenia zadowolenia z trwającego pobytu w województwie podkarpackim, planów odwiedzenia w najbliższym roku tych samych i nowych miejsc oraz polecenia znajomym i rodzinie tego regionu. Odpoczynek w województwie podkarpackim zdecydowanie $(65,3 \%)$ spełnił oczekiwania turystów. Deklarowali oni, że w ciągu najbliższych $12-18$ miesięcy zdecydowanie $(52,6 \%)$ lub raczej $(30,7 \%)$ chcieliby ponownie odwiedzić miejsca, w których byli podczas ostatniego pobytu. Większość respondentów zdecydowanie poleci $(74,6 \%)$ lub raczej poleci $(21,9 \%)$ pobyt $\mathrm{w}$ województwie podkarpackim swoim krewnym lub znajomym. Pobyt w województwie w większości przypadków $(66,3 \%)$ spełnił oczekiwania odwiedzających jednodniowych. Deklarowali oni, że w ciągu najbliższych 12-18 miesięcy zdecydowanie $(61,9 \%)$ lub raczej $(31,0 \%)$ chcieliby wrócić w miejsca, w których przebywali ostatnim razem. Większość respondentów zdecydowanie poleci $(68,7 \%)$ lub raczej poleci $(25,8 \%)$ swoim krewnym lub znajomym pobyt w regionie. Przeprowadzone analizy wykazały wysoki poziom lojalności ankietowanych - 95\% turystów i $96 \%$ odwiedzających jednodniowych można zaliczyć do grupy konsumentów lojalnych (suma wskazań „zdecydowanie lojalni" i „raczej lojalni”).

Wyniki badania pokazują wyraźnie, że do województwa przyjeżdżają turyści lojalni (wielokrotnie wracający, polecający). To właśnie oni przede wszystkim mogą być naturalnymi ambasadorami marki.

\section{PODSUMOWANIE I WNIOSKI}

Zaprezentowane $\mathrm{w}$ tekście analizy prowadzą do wniosku, że konsekwencje pandemii COVID-19 dla regionalnej branży turystycznej nie są jednoznacznie pozytywne lub negatywne. Pandemia wpłynęła negatywnie na wielkość ruchu turystycznego w województwie podkarpackim. Szacuje się, że zamiast możliwych 1400000 turystów przybyło co najwyżej niespełna 920 000. Spadek ten miał przełożenie na straty finansowe odnotowane w branży turystycznej. Analizując odpowiedzi respondentów na pytania dotyczące skali wydatków, można stwierdzić, że w 2020 r. województwo podkarpackie straciło od 275 do 323 mln złotych. Ruch turystyczny mieszkańców województwa podkarpackiego nie mógł skompensować tej straty i z oczywistych względów nie rzutował też na dopływ gotówki z zewnątrz (był to obrót pieniędzy wewnątrz regionu).

Straty w największym stopniu dotknęły turystykę miejską. Stagnację zaobserwowano w szczególności 
w turystyce biznesowej, kongresowej, eventowej i szkoleniowej. Znacznemu ograniczeniu uległy turystyka międzynarodowa oraz ruch tranzytowy.

Turyści ze względów bezpieczeństwa wybierali wypoczynek w pobliżu miejsca zamieszkania lub w sąsiednich regionach (województwach). Starali się unikać miejsc o dużej koncentracji ludności. Preferowali wypoczynek aktywny, co mogło wynikać z chęci odreagowania po dość długim czasie izolacji i ograniczeń. Jednym z takich regionów była południowa część województwa podkarpackiego (szczególnie Bieszczady), gdzie odnotowano wzrost liczby turystów oraz zauważono, że przedstawiciele branży turystycznej zasadniczo chwalili sezon letni.

Nie wiadomo, jak długo przyjdzie nam się mierzyć z obecną sytuacją i funkcjonować w warunkach ograniczeń spowodowanych pandemią. Być może COVID-19 zostanie z nami na dłużej, lub nawet na zawsze. Będziemy musieli nauczyć się z tym żyć oraz zacząć postrzegać turystykę trochę inaczej niż dotychczas. Mając świadomość nieuniknionych zmian, wielu zarządzających i przedsiębiorców związanych z turystyką już dziś powinno skupiać swoje działania na przygotowaniu planów, które pozwolą im funkcjonować w odmiennej rzeczywistości. Zaprezentowane w niniejszym artykule wyniki badań, spostrzeżenia i wnioski mogą być pomocne w realizacji tych zamierzeń. Równocześnie wskazane jest dalsze monitorowanie zjawiska, w celu uchwycenia zmian i tendencji w turystyce regionalnej. Przedstawione w niniejszej publikacji analizy i dane dotyczą branży turystycznej na terenie województwa podkarpackiego i ze względu na jego specyfikę powinny w ograniczonym zakresie stanowić powód do generalizowania uzyskanych wyników.

\section{PRZYPISY}

\begin{abstract}
${ }^{1}$ Wskazane lokalizacje to: Rynek w Rzeszowie, Solina - zapora w Solinie, Uherce Mineralne - Bieszczadzkie Drezyny Rowerowe, Majdan - Bieszczadzka Kolejka Leśna, Wetlina - wejście na szlak na Przełęcz Orłowicza, Cisna - centrum, Wołosate - punkt kasowy przy szlaku na Tarnicę, Ustrzyki Górne - centrum, Ustrzyki Dolne - centrum, Przełęcz Wyżniańska - parking przy wejściu na Połoninę Caryńską oraz Wielką i Małą Rawkę.

${ }^{2}$ Wszystkie aspekty definicyjne związane z ruchem turystycznym oraz rodzajami turystyki opracowano na podstawie: Gaworecki (2010); Kurek, Mika (2008).
\end{abstract}

\section{REFERENCES/BIBLIOGRAFIA}

Astakhova, L.V. (2019). The concept of student cognitive culture: Definition and conditions for development. The Education and Science Journal, 21 (10), 89-115. https://doi. org/10.17853/1994-5639-2019-10-89-115
Ayittei, F., Ayittei, M., Chiwero, N., Kamasah, J., Dzuvor, C. (2020). Economic impacts of Wuhan 2019-nCoV ON China and the world. Journal of Medical Virology, 92, 473-475. https:// doi.org/10.1002/jmv.25706

Badanie potencjału turystycznego regionu i preferencji grupy docelowej na potrzeby tworzenia nowych produktów transgranicznych w województwie podkarpackim. Raport z badań ilościowych (2018). Rzeszów: Exacto Sp. z o.o.. Retrieved from: https://podkarpackie.travel/assets/media/prot-raport.pdf (11.02.2021).

Badanie ruchu turystycznego przyjazdowego w województwie podkarpackim (2011). Raport z badań opracowany na zlecenie Urzędu Marszałkowskiego Województwa Podkarpackiego, MillwardBrown SMG/KRC, Warsaw. Retrieved from: http:// www.umwp.podkarpackie.pl/images/stories/res/um/tur/11/ raport $\% 20$ z $\% 20$ bada $\% 20$ ruchu $\% 20$ turystycznego $\% 20 \mathrm{w} \% 20$ woj.\%20podkarpackim_2011.pdf (11.02.2021).

Baran-Zgłobicka, B. (2013). Sacrum w krajobrazie kulturowym województwa podkarpackiego - zasoby oraz rola w turystyce i promocji regionu. Prace Komisji Krajobrazu Kulturowego, 19, 88-103.

Bernaś, B., Pujer, K. (2014). Bezpieczeństwo i zagrożenia w turystyce. ZN WSB we Wroctawiu, 15 (2), 223-243.

Carson, D., Richards, F., Rose, S. (2004). A framework for assessing the innovation potential of Australia's Regional Tourism Systems. Paper presented to the CAUTHE Conference, Brisbane, Queensland, February.

Castanho, R.A., Couto, G., Pimentel, P., Carvalho, C.B., Sousa, Á. (2020). Territorial management and governance, regional public policies and their relationship with tourism. A case study of the Azores Autonomous Region. Sustainability, 12, 6059. https://doi.org/10.3390/su12156059

Chang, C.L., McAleer, M., Ramos, V.A. (2020). Charter for sustainable tourism after COVID-19. Sustainability, 12, 3671. https://doi.org/10.3390/su12093671

Chojnicki, Z., Czyż, T. (1992). Region - regionalizacja - regionalizm. Ruch Prawniczy, Ekonomiczny i Socjologiczny, LIV (2), $1-18$.

Couto, G., Castanho, R.A., Pimentel, P., Carvalho, C., Sousa, A., Santos, C. (2020). The impacts of COVID-19 crisis over the tourism expectations of the Azores Archipelago residents. Sustainability, 12 (18), 7612. https://doi.org/10.3390/su12187612

Durydiwka, M. (2011). Dziedzictwo kulturowe jako czynnik rozwoju funkcji turystycznej - na przykładzie gmin bieszczadzkich. Prace Geograficzne, 125, 37-61.

Durydiwka, M. (2012). Czynniki rozwoju i zróżnicowanie funkcji turystycznej na obszarach wiejskich w Polsce. Warsaw: Uniwersytet Warszawski, Wydział Geografii i Studiów Regionalnych.

Filozof, T.J. (2019). Historia podkarpackich zdrojowisk. Karpacki Przeglad Społeczno-Kulturalny, 7 (38), 24-26.

Flew, T., Kirkwood, K. (2021). The impact of COVID-19 on cultural tourism: Art, culture and communication in four regional sites of Queensland, Australia. Media International Australia, 178 (1), 16-20. https://doi.org/10.1177/1329878X20952529

Folinas, S., Metaxas, T. (2020). Tourism: The great patient of coronavirus COVID-2019. Munich Personal RePEc Archive Paper, 99666, 1-14. https://doi.org/10.21474/IJAR01/10788

Frekwencja na szlakach w 2019 roku. Bieszczadzki Park Narodowy. Retrieved from: https://www.bdpn.pl/index.php?option=com_ content\&task=view\&id=2736\&Itemid=1 (9.03.2021).

Gaworecki, W. (2010). Turystyka. Warsaw: Wydawnictwo Naukowe PWN.

Gierczak-Korzeniowska, B. (2019). An analysis of the condition of the tourist brand and tourist attractiveness of the Podkarpackie Region based on the Brand Asset Valuator Model. Polish Journal of Sport and Tourism, 26 (2), 34-39. https:// doi.org/10.2478/pjst-2019-0012 
Gołembski, G. (2005). Kompendium wiedzy o turystyce. Warsaw: Wydawnictwo Naukowe PWN.

Gołembski, G. (2020). Turystyka w czasach pandemii. Analiza i prognoza skutków pandemii dla polskiej branży turystycznej w perspektywie półrocznej. Retrieved from: https://www.wot. org.pl/2020/06/turystyka-w-czasach-pandemii-analiza-i-prognoza-skutkow-pandemii-dla-polskiej-branzy-turystycznej-w-perspektywie-polrocznej (9.03.2021).

Jędrzejowska, K., Wróbel, A. (2020). Wielki lockdown i deglobalizacja: wpływ pandemii COVID-19 na gospodarkę światową. Rocznik Strategiczny, 21, 1-26.

Krupa, J., Mantaj, A. (2017). The importance of traditional and regional food products in culinary tourism of the Podkarpackie Province. Folia Turistica, 45, 95-117. https://doi. org/10.5604/01.3001.0012.0516

Krupa, J., Zieliński, K. (2015). Rozwój turystyki kulinarnej w województwie podkarpackim i na obszarach pogranicza czynnikiem zachowania i promocji dziedzictwa kulturowego. In: K. Szpara, B. Zawilińska, A. Wilkońska (eds), Lokalny potencjał a zrównoważony rozwój turystyki w Karpatach (pp. 103-121). WarsawRzeszów: Centrum UNEP/GRID-Warszawa. https://doi. org/10.5604/01.3001.0012.0516

Kurek, W. (ed.) (2007). Turystyka. Warsaw: Wydawnictwo Naukowe PWN.

Kurek, W., Mika, M. (2008). Turystyka jako przedmiot badań naukowych. In: W. Kurek (ed.) Turystyka. Warsaw: Wydawnictwo Naukowe PWN.

Lee, J.W., McKibbin, W. (2004). Globalization and disease: The case of SARS. Asian Economic Papers, 3 (1), 13-31. https://doi. org/10.1162/1535351041747932

Madani, A., Boutebal, S.E., Benhamida, H., Bryant Ch.R. (2020). The impact of Covid-19 outbreak on the tourism needs of the Algerian population. Sustainability, 12, 8856. https://doi. org/10.3390/su12218856

Manzoor, F., Wei, L., Asif, M. (2019). The contribution of sustainable tourism to economic growth and employment in Pakistan. International Journal of Environmental Research and Public Health, 16 (19), 3785. https://doi.org/10.3390/ijerph16193785

Marszałek, E. (2020). Lasy podkarpackie dla turystyki. Karpacki Przeglad Społeczno-Kulturalny, 4 (43), 27-29.

Milova, Y.Y., Piskovets, E.L., Chernyshenko, M.S. (2017). Challenges and opportunities for regional tourism development, advances in economics. Business and Management Research, 38, 438-442. https://doi.org/10.2991/ttiess-17.2017.72

Mirchandani, R. (2020). Five global issues to watch in 2021. United Nations Foundation, 23 December 2020. Retrieved from: https://unfoundation.org/blog/post/five-global-issues-to-watch-in-2021/ (17.10.2021).

Mniej turystów w okresie wakacyjnym (2020). Retrieved from: https:// rzeszow.stat.gov.pl/files/gfx/rzeszow/pl/defaultaktualnosci/73/261/1/1/turystyka_wakacje_2020_poprawiony.docx. $\operatorname{pdf}(15.11 .2021)$.

Mróz, F., Mróz, Ł. (2012). Sanktuaria i ośrodki pielgrzymkowe na Pogórzu Dynowskim - geneza i funkcjonowanie. In: J. Krupa, T. Soliński (eds), Ochrona środowiska w aspekcie zrównoważonego rozwoju społeczno-gospodarczego Pogórza Dynowskiego (pp. 125149). Dynów: Związek Gmin Turystycznych Pogórza Dynowskiego.

Nizioł, A. (2016). Rola produktów lokalnych w rozwoju funkcji turystycznej regionu na przykładzie Podkarpacia. Annales Universitatis Mariae Curie-Sklodowska, sectio B - Geographia, Geologia, Mineralogia et Petrographia, 71 (2), 103-115. https:// doi.org/10.17951/b.2016.71.2.103

Nycz, E. (2019). Analiza frekwencji turystycznych w obiektach turystycznych w woj. podkarpackim. Karpacki Przeglad SpołecznoKulturalny, 6 (37), 30-33.
Pawlusiński, R. (2009). Turystyka w województwie podkarpackim. Folia Geographica. Series Geographica-Oeconomica, XXXIII, 119-136.

Pierret, F. (2011). Some points on domestic tourism. UNWTO Executive Director. Retrieved from: http://dtxtq4w60xqpw. cloudfront.net/sites/all/files/elements_on_domestic_tourism. pdf (20.06.2021).

Ponte, J., Couto, G., Pimentel, P., Oliveira, A., (2018). Tourism activities and companies in a sustainable adventure tourism destination: The Azores. Tourism and Management Studies, 14, 25-38. https://doi.org/10.18089/tms.2018.14403

Reczek, J. (2019). Z historii wina na Podkarpaciu i o odmianach winorośli. Karpacki Przeglad Społeczno-Kulturalny, 8 (39), 15.

Ren, J. (2020). Fare impacts of Southwest Airlines: A comparison of nonstop and connecting flights. Journal of Air Transport Management, 84, 101-106. https://doi.org/10.1016/j. jairtraman.2020.101771

Rocznik statystyczny województwa podkarpackiego - 2020 (2020). Retrieved from: https://rzeszow.stat.gov.pl/publikacje-i-foldery/roczniki-statystyczne/rocznik-statystyczny-wojewodztwa-podkarpackiego-2020,5,17.html (4.02.2021).

Rogerson, C.M. (2017). Tourism - a new economic driver for South Africa. In: A. Lemon, C.M. Rogerson (eds), Geography and economy in South Africa and its neighbours (pp. 95-110). London: Routledge. https://doi.org/10.4324/9781315254463-6

Rogerson, Ch.M., Kiambo, W. (2007). The growth and promotion of regional tourism in the developing world: The South African experience. Development Southern Africa, 24 (3), 505-521. https:// doi.org/10.1080/03768350701445608

Romão, J., Guerreiro, J., Rodrigues, P. (2012). Regional tourism development: Culture, nature, life cycle and attractiveness. Current Issues in Tourism, 16 (6), 1-18. https://doi.org/10.1080 /13683500.2012.699950

Rut, J. (2002). Turystyka aktywna w Euroregionie Karpackim. Rzeszów: Wydawnictwo Uniwersytetu Rzeszowskiego.

Sigala, M. (2020). Tourism and COVID-19: Impacts and implications for advancing and resetting industry and research. Journal Bussiness Research, 117, 312-321. https://doi.org/10.1016/j. jbusres.2020.06.015

Sjafii, A., Pratiwi, N.M.I. (2018). Policy of regional tourism development. Prosiding Semnasfi, 1 (1), 333-343. https://doi. org/10.21070/semnasfi.v1i1.1153

Skulimowska, M. (2014). Rozwój turystyki kulturowej w oparciu o zasoby dziedzictwa materialnego na terenie gmin Pogórza Dynowskiego. In: J. Krupa (ed.), Zrównoważona turystyka szansa ochrony środowiska naturalnego, dziedzictwa kulturowego i rozwoju gospodarczego gmin Pogórza Dynowskiego (pp. 241-252). Dynów: Związek Gmin Turystycznych Pogórza Dynowskiego.

Ślusarz, G., Cierpiał-Wolan, M., Gierczak-Korzeniowska, B., Uchman, J., Żegleń, P. (2019). Potencjat turystyczny i jego wykorzystanie w latach 2014-2018 - ujęcie regionalne. Rzeszów: Wydawnictwo Uniwersytetu Rzeszowskiego.

Śmiały, A. (2007). Uwarunkowania rozwoju turystyki aktywnej w Czarnorzecko-Strzyżowskim Parku Krajobrazowym. Prace Geograficzne, 117, 165-180.

Stokłosa, Ł., Marchiori, E., Piotrowski, M., Cantoni, L. (2013). The use of destination online reputation model to evaluate a tourism destination. The case of Podkarpackie region. Folia Turistica, 28 (2), 131-150.

Szmuc, R. (2009). Przyrodnicza przestrzeń turystyczna województwa podkarpackiego. Annales Universitatis Mariae Curie-Skłodowska. Sectio B, Geographia, Geologia, Mineralogia et Petrographia, 64 (1), 53-66.

Szpara, K. (2011a). Agroturystyka w Karpatach Polskich. Prace Geograficzne, 125, 161-178.

Szpara, K. (2011b). Przyjazdowy ruch turystyczny w województwie podkarpackim w 2009 r. In: M. Soja, A. Zborowski (eds), 
Człowiek w przestrzeni zurbanizowanej (pp. 239-251). Cracow: Instytut Geografii i Gospodarki Przestrzennej UJ.

Szpara, K. (2015). Aktywność turystyczna seniorów - na przykładzie turystów-obcokrajowców przebywających na terenie województwa podkarpackiego w 2012 roku. Ekonomiczne Problemy Turystyki, 1 (29), 287-301.

Szpara, K. (2020). Potencjał przyrodniczy Pogórza Dynowskiego i możliwości jego wykorzystania w turystyce. In: J. Krupa, K. Szpara (eds), Zrównoważony rozwój społeczno-gospodarczy determinanta ochrony dóbr przyrodniczych i kulturowych oraz rozwoju turystyki (pp. 17-29). Dynów: Związek Gmin Turystycznych Pogórza Dynowskiego, Oficyna Wydawnicza Politechniki Rzeszowskiej.

Szpara, K., Drupka, J., Krupa, J., Skała, M., Bwanakare, S., Gwóźdź, M. (2009). Badanie przyjazdowego ruchu turystycznego w wybranych miejscach recepcji turystycznej województwa podkarpackiego w okresie V-IX 2009 roku. Retrieved from: http://www.rpo.podkarpackie.pl/attachments/article/279/ Za\%C5\%82\%C4\%85cznik\%206f.pdf (11.02.2021).

Szpara, K., Gierczak-Korzeniowska, B., Stopa, M. (2020a). Metodologia cyklicznych badań ruchu turystycznego w województwie podkarpackim. Rzeszów: Podkarpacka Regionalna Organizacja Turystyczna. Retrieved from: https://podkarpackie.travel/assets/media/metodologia-cyklicznych-badan-ruchu-turystycznego-w-woj-podkarpackim-15-05-2020.pdf (11.02.2021).

Szpara, K., Gierczak-Korzeniowska, B., Stopa, M. (2020b). Raport $z$ badań ruchu turystycznego w województwie podkarpackim w 2020 roku. Rzeszów: Podkarpacka Regionalna Organizacja Turystyczna. Retrieved from: https://podkarpackie.travel/pl/ blog/-badania\%20ruchu5 (11.02.2021).
Szpara, K., Skała, M. (2008). Kadry turystyczne w województwie podkarpackim w 2008 roku - na przykładzie przewodników turystycznych i pilotów wycieczek. Ekonomiczne Problemy Ustug, 19, 209-215.

Tornos News (2020). Cyprus tourism hopes warmer weather would end the coronavirus crisis. Retrieved from: https://www. tornosnews.gr/en/tourism-businesses/markets/39309-cyprus-tourism (7.03.2021).

Tracz, M., Bajgier-Kowalska, M., Uliszak, R. (2017). The development of agritourism in the Podkarpackie Voivodeship in the light of international and national conditions. PrzedsiębiorczośćEdukacja, 13, 244-261. https://doi.org/10.24917/20833296.13.18

Turystyka na Podkarpaciu w 2020 roku (2021). Retrieved from: https://rzeszow.stat.gov.pl/dla-mediow/informacje-prasowe/turystyka-na-podkarpaciu-w-2020-roku,268,1.html (29.03.2021).

Turystyka w województwie podkarpackim w 2019 r. (2020). Retrieved from: https://rzeszow.stat.gov.pl/opracowania-biezace/opracowania-sygnalne/sport-turystyka/turystyka-w-wojewodztwie-podkarpackim-w-2019-r-,2,17.html (4.02.2021).

Widak, L. (2020a). Turystyka konna w województwie podkarpackim. Karpacki Przegląd Społeczno-Kulturalny, 5 (44), 24-26.

Widak, L. (2020b). Zrównoważone trasy rowerowe typu „singletrack". Karpacki Przeglad Społeczno-Kulturalny, 4 (43), 22-23.

Więckowski, M. (2020). Natural heritage as a resource for tourism development in the Polish Carpathians. Geografický Časopis / Geographical Journal, 72 (3), 243-259. https://doi.org/10.31577/ geogrcas.2020.72.3.12

Zieliński, K. (2019). Tropem podkarpackim tradycyjnych smaków. Karpacki Przeglad Społeczno-Kulturalny, 6 (37), 22 